\title{
Enantioseletive Total Synthesis of (-)-Clavosolide B
}

\author{
Jung Beom Son, Min-ho Hwang, Wonsun Lee, and Duck Hyung Lee* \\ Department of Chemistry, Sogang University, Shinsoo-dong 1, Mapo-gu \\ Seoul, 121-742, Korea \\ E-mail:dhlee@sogang.ac.kr
}

\section{Supporting Information}

All reactions were carried out under an atmosphere of nitrogen in flame-dried or oven-dried glassware with magnetic stirring. Air sensitive reagents and solutions were transferred via syringe or cannula and were introduced to the apparatus through rubber septa. Tetrahydrofuran $(\mathrm{THF})$, diethyl ether $\left(\mathrm{Et}_{2} \mathrm{O}\right)$ and toluene were distilled from sodium/benzophenone ketyl. Dichloromethane was distilled from phosphorous pentoxide. Triethylamine (TEA) and other nitrogen containing bases were distilled from calcium hydride under nitrogen atmosphere prior to use. Methanol was distilled from sodium. Reactions were monitored by thin layer chromatography (TLC) with $0.25 \mathrm{~mm}$ E. Merck pre-coated silica gel plates $\left(60 \mathrm{~F}_{254}\right)$. Visualization was accomplished with either UV light, or by immersion in solutions of $p$ anisaldehyde, or phosphomolybdic acid (PMA) followed by heating on a hot plate for $\sim 15$ sec. Purification of reaction products was carried out by flash chromatography using EM Reagent silica gel 60 (230-400 mesh). Melting points were determined using a Thomas-Hoover capillary melting point apparatus and are uncorrected. ${ }^{1} \mathrm{H}-\mathrm{NMR}$ and ${ }^{13} \mathrm{C}-\mathrm{NMR}$ spectra were obtained using a Varian Gemini-300 (300 MHz for ${ }^{1} \mathrm{H}$, and $75 \mathrm{MHz}$ for ${ }^{13} \mathrm{C}$ ), or a Varian Inova-500 (500 MHz for ${ }^{1} \mathrm{H}$, and $125 \mathrm{MHz}$ for ${ }^{13} \mathrm{C}$ ) spectrometer. Chemical shifts are reported relative to chloroform $(\delta 7.26)$ for ${ }^{1} \mathrm{H}$ NMR and chloroform $(\delta$ 77.2) for ${ }^{13} \mathrm{C}$ NMR. Data are reported as $(\mathrm{br}=$ broad, $\mathrm{s}=$ singlet, $\mathrm{d}=$ doublet, $\mathrm{t}=$ triplet, $\mathrm{q}=$ quartet, $\mathrm{m}=$ multiplet; coupling constant(s) in Hz). Ambiguous assignments were resolved on the basis of standard one dimensional proton decoupling experiments. Elemental analyses were performed by the Organic Chemistry Research Center at Sogang University using a Carlo Erba EA 1180 elemental analyzer. Optical rotations were obtained using a Rudolph Autopol III digital polarimeter and optical rotation data was reported as follows: $[\alpha]_{D}^{25}$ (concentration $c=\mathrm{g} / 100 \mathrm{~mL}$, solvent). High resolution mass spectra were recorded on a 4.7 Tesla IonSpec ESI-FTMS or a Micromass LCT ESI-TOF mass spectrometer. All commercially available compounds were used as received unless stated otherwise. 
Preparation of 4-benzyl-3-(3-hydroxy-hex-4-enoyl)-oxazolidin-2-one (4)

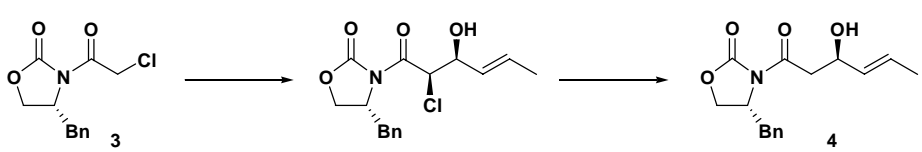

Aldol reaction: To a $-78{ }^{\circ} \mathrm{C}$ solution of chloroacetyl oxazolidinone 3 (6.32 g, $\left.24.93 \mathrm{mmol}\right)$ in $\mathrm{CH}_{2} \mathrm{Cl}_{2}$ $(70 \mathrm{~mL})$ was added diisopropylethylamine $(6.08 \mathrm{~mL}, 34.01 \mathrm{mmol})$ and a solution of $\mathrm{Bu}_{2} \mathrm{BOTf}^{\text {in }} \mathrm{CH}_{2} \mathrm{Cl}_{2}$ (1.0 M, $30.0 \mathrm{~mL}, 29.9 \mathrm{mmol})$. The cooling bath was removed and the solution was stirred at room temperature for $1.5 \mathrm{~h}$. The reaction mixture was cooled to $-78{ }^{\circ} \mathrm{C}$, and was added crotonaldehyde (9.89 $\mathrm{mL}, 37.4 \mathrm{mmol})$ in methylene chloride $(13 \mathrm{~mL})$. The mixture was stirred at $-78{ }^{\circ} \mathrm{C}$ for $1 \mathrm{~h}$ and $0{ }^{\circ} \mathrm{C}$ for $2 \mathrm{~h}$. The resulting solution with $\mathrm{MeOH}(119.8 \mathrm{~mL})$ at $0{ }^{\circ} \mathrm{C}$, followed by buffer solution $(\mathrm{pH} 7,60 \mathrm{~mL})$ and hydrogen peroxide $(30 \%, 60 \mathrm{~mL})$ and stirring continued for $1 \mathrm{~h}$. The organic phase was separated and the aqueous layer extracted with $\mathrm{CH}_{2} \mathrm{Cl}_{2}$ (X2). The combined organic phases were washed with brine, dried $\mathrm{MgSO}_{4}$, and concentrated in vacuo. The crude residue was purified by column chromatography (EtOAc:Hex $=1: 2)$ to give desired aldol adduct $\left(4.18 \mathrm{~g}, 52 \%\right.$ ) as a yellow oil: $[\alpha]_{D}^{25}-65.5$ (c 0.42 , $\left.\mathrm{CHCl}_{3}\right)$; IR (neat) 3417, 3029, 1789, 1480, 1392, 1111; ${ }^{1} \mathrm{H} \mathrm{NMR}\left(\mathrm{CDCl}_{3}, 500 \mathrm{MHz}\right) \delta=7.35(\mathrm{t}, J=7 \mathrm{~Hz}$, 2H), 7.31-7.25 (m, 1H), $7.22(\mathrm{~d}, J=7 \mathrm{~Hz}, 2 \mathrm{H}), 5.88(\mathrm{td}, J=6.5,1 \mathrm{~Hz}, 1 \mathrm{H}), 5.69(\mathrm{~d}, J=5 \mathrm{~Hz}, 1 \mathrm{H}), 5.56$ $(\mathrm{dd}, J=5.5,2 \mathrm{~Hz}, 1 \mathrm{H}), 4.73-4.67(\mathrm{~m}, 1 \mathrm{H}), 4.62-4.57(\mathrm{~m}, 1 \mathrm{H}), 4.24(\mathrm{~d}, J=4 \mathrm{~Hz}, 2 \mathrm{H}), 3.31(\mathrm{dd}, J=13.5$, $3.5 \mathrm{~Hz}, 1 \mathrm{H}), 2.83(\mathrm{dd}, J=14,9.5 \mathrm{~Hz}, 1 \mathrm{H}), 2.71(\mathrm{~d}, J=4.5 \mathrm{~Hz}, 1 \mathrm{H}), 1.74(\mathrm{~d}, J=6 \mathrm{~Hz}, 3 \mathrm{H}) \mathrm{ppm} ;{ }^{13} \mathrm{C}$ NMR $\left(\mathrm{CDCl}_{3}, 125 \mathrm{MHz}\right) \delta=168.0,152.8,134.8,134.8,131.3,129.6,129.3,128.0,127.6,72.8,66.7$, 59.7, 55.6, 37.4, 18.0 ppm; HRMS (EI):m/z calcd for $\mathrm{C}_{16} \mathrm{H}_{18} \mathrm{ClNNaO}_{4}(\mathrm{M}+\mathrm{Na}) 346.0822$, found 346.0820

Dehalogenation: To a solution of the aldol adduct $(7.26 \mathrm{~g}, 22.4 \mathrm{mmol})$ in $150 \mathrm{~mL}$ of methanol and treated with zinc powder $(5.86 \mathrm{~g}, 89.7 \mathrm{mmol})$ and ammonium chloride $(4.8 \mathrm{~g}, 89.7 \mathrm{mmol})$, and the resulting suspension vigorously stirred for $5 \mathrm{~min}$ at room temperature. After $5 \mathrm{~min}$, the reaction mixture was filtered, and filtrate was concentrated in vacuo. The crude product was purified on silica gel ( $n$ Hex:EtOAc $=2: 1)$ to afford pure product $4(4.74 \mathrm{~g}, 73 \%)$ as a white semi-solid: $[\alpha]_{D}^{25}-35.3$ (c 0.54 , $\mathrm{CHCl}_{3}$ ); IR (neat) 3434, 3031, 2982, 2952, 2916, 1789, 1707, 1492, 1477, 1392, 1371, 1302, 1244, 1210, 1113, 1050, 1024; ${ }^{1} \mathrm{H} \mathrm{NMR}\left(\mathrm{CDCl}_{3}, 500 \mathrm{MHz}\right) \delta=7.34(\mathrm{t}, J=7 \mathrm{~Hz}, 2 \mathrm{H}), 7.29(\mathrm{~d}, J=7.5 \mathrm{~Hz}, 1 \mathrm{H}), 7.2$ $1(\mathrm{~d}, J=7 \mathrm{~Hz}, 2 \mathrm{H}), 5.79(\mathrm{ddd}, J=15,6.5,1 \mathrm{~Hz}, 1 \mathrm{H}), 5.77(\mathrm{ddd}, J=16,7,1.5 \mathrm{~Hz}, 1 \mathrm{H}), 4.73-4.67(\mathrm{~m}$, $1 \mathrm{H}), 4.69-4.54(\mathrm{~m}, 1 \mathrm{H}), 4.20$ (d, $J=3 \mathrm{~Hz}, 2 \mathrm{H}), 3.29$ (dd, $J=14,3.5 \mathrm{~Hz}, 1 \mathrm{H}), 3.20$ (d, $J=9 \mathrm{~Hz}, 1 \mathrm{H}), 3.14$ $(\mathrm{d}, J=3.5 \mathrm{~Hz}, 1 \mathrm{H}), 2.93(\mathrm{~d}, J=4.5 \mathrm{~Hz}, 1 \mathrm{H}), 2.80(\mathrm{dd}, J=13.5,9.5 \mathrm{~Hz}, 1 \mathrm{H}), 1.72(\mathrm{~d}, J=7.5 \mathrm{~Hz}, 3 \mathrm{H})$ ppm; ${ }^{13} \mathrm{C} \mathrm{NMR}\left(\mathrm{CDCl}_{3}, 125 \mathrm{MHz}\right) \delta=172.5,135.2,132.0,130.0,129.2,127.8,127.6,94.9,69.0,66.5$, 55.3, 43.0, 38.0, 17.9 ppm; HRMS (EI):m/z calcd for $\mathrm{C}_{17} \mathrm{H}_{21} \mathrm{NNaO}_{4}(\mathrm{M}+\mathrm{Na}) 326.1368$, found 326.1364 


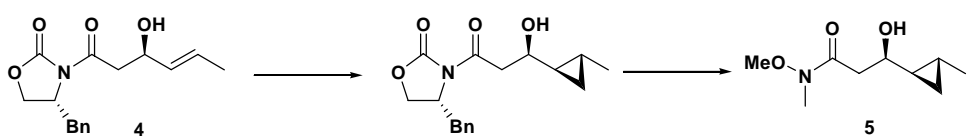

Cyclopropanation: Under an nitrogen atmosphere, a solution of allyl alcohol 4 (4.74 g, $16.4 \mathrm{mmol})$ in $\mathrm{CH}_{2} \mathrm{Cl}_{2}(102 \mathrm{~mL})$ was cooled to $-10{ }^{\circ} \mathrm{C}$, and diethyl zinc $(82 \mathrm{~mL}, 81.9 \mathrm{mmol}, 1.0 \mathrm{M}$ solution in hexane) and diiodomethane $(6.6 \mathrm{~mL}, 81.9 \mathrm{mmol})$ were added dropwise. After being stirred vigorously for $3 \mathrm{~h}$ at 10 to $0{ }^{\circ} \mathrm{C}$, the reaction mixture was treated with aqueous $\mathrm{NH}_{4} \mathrm{Cl}$ and extracted with $\mathrm{CH}_{2} \mathrm{Cl}_{2}$. The methylene chloride phase was washed with water and brine. The combined organic layers were dried over anhydrous $\mathrm{MgSO}_{4}$. After removal of the solvent, the residue was chromatographed on silica gel (EtOAc:Hex $=1: 2)$ to give cyclopropanated product $(4.82 \mathrm{~g}, 97 \%)$ as a semi-solid: $[\alpha]_{D}^{25}-43.2(\mathrm{c} 0.50$, $\mathrm{CHCl}_{3}$ ); IR (neat) 3453, 3031, 3006, 2956, 2920, 1785, 1707, 1457, 1388, 1371, 1356, 1306, 1203, 1113 , 1049, 1023; ${ }^{1} \mathrm{H} \mathrm{NMR}\left(\mathrm{CDCl}_{3}, 500 \mathrm{MHz}\right) \delta=7.34(\mathrm{t}, J=7 \mathrm{~Hz}, 2 \mathrm{H}), 7.29(\mathrm{~d}, J=7 \mathrm{~Hz}, 1 \mathrm{H}), 7.21(\mathrm{~d}, J=$ $7.5 \mathrm{~Hz}, 2 \mathrm{H}), 4.73-4.66(\mathrm{~m}, 1 \mathrm{H}), 4.25-4.16(\mathrm{~m}, 2 \mathrm{H}), 3.50-3.43(\mathrm{~m}, 1 \mathrm{H}), 3.33-3.18(\mathrm{~m}, 3 \mathrm{H}), 2.80(\mathrm{dd}, J=$ 13.5, 9.5 Hz, 1H), $2.75(\mathrm{~d}, J=4.5 \mathrm{~Hz}, 1 \mathrm{H}), 1.05$ (d, $J=4.5 \mathrm{~Hz}, 3 \mathrm{H}), 0.77-0.71(\mathrm{~m}, 1 \mathrm{H}), 0.70-0.63(\mathrm{~m}$, $1 \mathrm{H}), 0.62-0.56(\mathrm{~m}, 1 \mathrm{H}), 0.38-0.32(\mathrm{~m}, 1 \mathrm{H}) \mathrm{ppm} ;{ }^{13} \mathrm{C} \mathrm{NMR}\left(\mathrm{CDCl}_{3}, 125 \mathrm{MHz}\right) \delta=172.7,153.7,135.3$, 129.6, 129.2, 127.6, 72.2, 66.5, 55.3, 43.0, 38.0, 25.7, 18.5, 11.9, 10.8 ppm; HRMS (EI):m/z calcd for $\mathrm{C}_{16} \mathrm{H}_{18} \mathrm{NNaO}_{4}(\mathrm{M}+\mathrm{Na}) 326.1368$, found 326.1362

Transamination: To a suspension of $\mathrm{N}, \mathrm{O}$-dimethylhydroxylamine hydrochloride (327 $\mathrm{mg}, 3.349 \mathrm{mmol})$ in THF $(2 \mathrm{~mL})$ at $0{ }^{\circ} \mathrm{C}$ was added a solution of trimethylaluminum in toluene $(2.0 \mathrm{M}, 1.67 \mathrm{~mL}, 3.349$ $\mathrm{mmol}$ ) dropwise. The resulting homogeneous solution was stirred at room temperature for $50 \mathrm{~min}$. The reaction mixture was cooled to $0{ }^{\circ} \mathrm{C}$, and a solution of cycloprpanated product $(254 \mathrm{mg}, 0.837 \mathrm{mmol})$ in THF $(0.8 \mathrm{~mL})$ was added via syringe. The reaction mixture was stirred at $0{ }^{\circ} \mathrm{C}$ for $2 \mathrm{~h}$ and at room temperature for $0.5 \mathrm{~h}$. The mixture was then poured into a solution of saturated aqueous sodium potassium tartrate. $\mathrm{Et}_{2} \mathrm{O}$ was added, and the mixture was stirred vigorously for $1 \mathrm{~h}$ until two clear layers were formed. The aqueous layer was extracted with EtOAc. The combined organic layers were washed with brine, dried over $\mathrm{MgSO}_{4}$, filtered and concentration. Purification via flash chromatography $(n$ Hex:EtOAc = 1:2) gave Weinreb amide $5(151 \mathrm{mg}, 96 \%)$ as a colorless oil: $[\alpha]_{D}^{25}-53.1\left(\mathrm{c} 0.53, \mathrm{CHCl}_{3}\right)$; IR (neat) 3450, 3316, 2950, 1758, 1643, 1453, 1392, 1245, 1183, 1030; ${ }^{1} \mathrm{H} \mathrm{NMR}\left(\mathrm{CDCl}_{3}, 500 \mathrm{MHz}\right) \delta=$ 3.71(s, 3H), 3.56(d, J = 2.5 Hz, 1H), 3.37(m, 1H), 3.20(s, 3H), 2.77(d, J = 17 Hz, 1H), 2.69-2.62(m, 1H), $1.04(\mathrm{~d}, \mathrm{~J}=6 \mathrm{~Hz}, 3 \mathrm{H}), 0.69-0.56(\mathrm{~m}, 3 \mathrm{H}), 0.35-0.30(\mathrm{~m}, 1 \mathrm{H}) \mathrm{ppm} ;{ }^{13} \mathrm{C} \mathrm{NMR}\left(\mathrm{CDCl}_{3}, 125 \mathrm{MHz}\right) \delta=165.2$, $72.2,61.5,38.6,32.1,25.5,18.6,11.8,10.5 \mathrm{ppm}$; HRMS (EI):m/z calcd for $\mathrm{C}_{9} \mathrm{H}_{17} \mathrm{NNaO}_{3}(\mathrm{M}+\mathrm{Na})$ 210.1106 , found 210.1109 


\section{Preparation of (S)-3-hydroxy-N-methoxy-N-methyl-3-((1R,2R)-2-methylcyclopropyl)propanamide}

(6)<smiles>CON(C)C(=O)CC(O)C1CC1C</smiles>

Mitsunobu reaction: To a suspension of $\mathrm{PPh}_{3}(378 \mathrm{mg}, 1.442 \mathrm{mmol})$ in toluene $(10 \mathrm{~mL})$ at $-45{ }^{\circ} \mathrm{C}$ was added DIAD $(0.34 \mathrm{~mL}, 1.71 \mathrm{mmol})$ dropwise. After stirring for $2 \mathrm{~min}$ at that temperature, $\mathrm{AcOH}(83 \mu \mathrm{L}$, $1.44 \mathrm{mmol})$ was added. The secondary alcohol $5(100 \mathrm{mg}, 0.534 \mathrm{mmol})$ in toluene $(4 \mathrm{~mL})$ was then quickly added dropwise, and the resulting solution stirred at $-45^{\circ} \mathrm{C}$ for $8 \mathrm{~h}$. After $8 \mathrm{~h}$ reaction time, the solvent was evaporated, and the residue was purified by flash chromatography (EtOAc:Hex $=1: 2)$ to afford acetate $(74.7 \mathrm{mg}, 61 \%)$. The ${ }^{1} \mathrm{H}$ and ${ }^{13} \mathrm{C}$ NMR data are consistent with those previously reported in the literature. ${ }^{1}$

Hydrolysis: To a solution of acetate $(994.4 \mathrm{mg}, 4.34 \mathrm{mmol})$ in $\mathrm{MeOH}(108 \mathrm{~mL})$ at $0{ }^{\circ} \mathrm{C}$ was added $\mathrm{K}_{2} \mathrm{CO}_{3}(660 \mathrm{mg}, 4.77 \mathrm{mmol})$. After being stirred for $17 \mathrm{~h}$ at $0{ }^{\circ} \mathrm{C}$, the reaction mixture was treated with aqueous $\mathrm{NH}_{4} \mathrm{Cl}$ and concentrated. The residue was diluted with EtOAc and washed with water and brine. The combined organic layers were dried over $\mathrm{MgSO}_{4}$, filtered, concentrated in vacuo. The residue was purified by column chromatography (EtOAc: Hex = 2:1) to give alcohol 6 (588.4 mg, 68\%). The ${ }^{1} \mathrm{H}$ and ${ }^{13} \mathrm{C}$ NMR data are consistent with those previously reported in the literature. ${ }^{1}$

\section{Preparation of 4-(4-methoxybenzyloxy)-4-(2-methylcyclopropyl)-butan-2-one (7)}

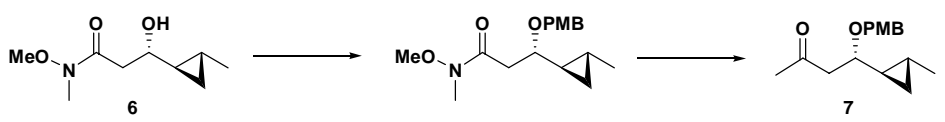

Protection. To a solution of the secondary alcohol 6 (1.22 g, $6.54 \mathrm{mmol})$ in $\mathrm{CH}_{2} \mathrm{Cl}_{2} / c$-hexane $(7 \mathrm{~mL} / 14$ $\mathrm{mL}$ ) was added a solution of $p$-methoxybenzyl 2,2,2-trichloroacetimidate $(3.7 \mathrm{~g}, 13.1 \mathrm{mmol})$ in $\mathrm{CH}_{2} \mathrm{Cl}_{2} / c$ hexane $(4 \mathrm{~mL} / 8 \mathrm{~mL})$ at room temperature. A catalytic amount of $\mathrm{TsOH} \cdot \mathrm{H}_{2} \mathrm{O}(62 \mathrm{mg})$ was added at room temperature and the reaction mixture was stirred for 1day at the temperature. The reaction was quenched with triethylamine, and excess $n$-hexane was added. Precipitates were filtered off, and the combined filtrates were concentrated in vacuo. The residue was diluted with $\mathrm{Et}_{2} \mathrm{O}$ and washed with water and brine. The combined organic layers were dried over $\mathrm{MgSO}_{4}$, filtered, evaporated to give crude product. The crude residue was purified by column chromatography (EtOAc:Hex $=1: 1)$ to give PMB protected amide (1.66 g, 83\%) as a colorless oil: $[\alpha]_{D}^{25}-8.9$ (c 1.12, $\left.\mathrm{CHCl}_{3}\right)$; IR (neat) 3060, 2994, 2941, 2864, 1658, 1617 ,

1 Smith, A. B., III; Simov, V. Org. Lett. 2006, 8, 3315-3318. 
1507, 1249, 1082, 1025, 820; ${ }^{1} \mathrm{H}$ NMR $\left(\mathrm{CDCl}_{3}, 500 \mathrm{MHz}\right) \delta=7.25(\mathrm{~d}, J=9 \mathrm{~Hz}, 2 \mathrm{H}), 6.85(\mathrm{~d}, J=9 \mathrm{~Hz}$, $2 \mathrm{H}), 4.66(\mathrm{~d}, J=11 \mathrm{~Hz}, 1 \mathrm{H}), 4.45(\mathrm{~d}, J=11 \mathrm{~Hz}, 1 \mathrm{H}), 3.79$ (s, $3 \mathrm{H}), 3.66(\mathrm{~s}, 3 \mathrm{H}), 3.31$ (dt, $J=4.5,8.5$ Hz, 1 H), 3.19 (s, 3 H), 2.93 (m, 1 H), 2.55 (dd, $J=4,15$ Hz, 1 H), 1.07 (d, $J=6$ Hz, 3 H), 0.76 (m, 1 H), $0.62(\mathrm{tt}, J=4.5,9 \mathrm{~Hz}, 1 \mathrm{H}), 0.30(\mathrm{dt}, J=4.5,9 \mathrm{~Hz}, 1 \mathrm{H}), 0.21(\mathrm{dt}, J=4.5,9 \mathrm{~Hz}, 1 \mathrm{H}) \mathrm{ppm} ;{ }^{13} \mathrm{C} \mathrm{NMR}$ $\left(\mathrm{CDCl}_{3}, 125 \mathrm{MHz}\right) \delta 172.6,159.1,129.4,129.3,113.8,80.1,71.1,61.5,55.4,38.3,32.3,24.0,18.5$, 13.6, 9.6 ppm; HRMS (EI):m/z calcd for $\mathrm{C}_{17} \mathrm{H}_{25} \mathrm{NNaO}_{4}(\mathrm{M}+\mathrm{Na}) 330.1681$, found 330.1683

Methyl Ketone formation: A solution of $(1.12 \mathrm{~g} 3.64 \mathrm{mmol})$ of PMB protected amide in $18 \mathrm{~mL}$ of THF at $-78{ }^{\circ} \mathrm{C}$ was added $1.46 \mathrm{~mL}(4.37 \mathrm{mmol})$ of a $3.0 \mathrm{M}$ solution of $\mathrm{MeMgCl}$ in THF in one portion. The reaction was warmed at $0{ }^{\circ} \mathrm{C}$ over $3 \mathrm{~h}$ followed by the addition of 0.1 equivalent of $\mathrm{MeMgCl}$ at $-10{ }^{\circ} \mathrm{C}$. After $1 \mathrm{~h}$ at $0{ }^{\circ} \mathrm{C}$, the solution was cooled to $-50{ }^{\circ} \mathrm{C}$ and diluted $\mathrm{Et}_{2} \mathrm{O}$ and saturated aqueous $\mathrm{NH}_{4} \mathrm{Cl}$. The layers were separated and the aqueous phase was extracted twice with $\mathrm{Et}_{2} \mathrm{O}$. Combined organic layers were washed with saturated aqueous $\mathrm{NaHCO}_{3}$ and brine, dried over anhydrous $\mathrm{MgSO}_{4}$ and concentrated in vacuo. Purification by flash chromatography (Hex : EtOAc $=2: 1)$ provided $820 \mathrm{mg}(86 \%)$ of the methyl ketone 7 as a colorless oil. The ${ }^{1} \mathrm{H}$ and ${ }^{13} \mathrm{C}$ NMR data are consistent with those previously reported in the literature. ${ }^{2}$

\section{Preparation of 2,3,4-tri-O-acetyl- $\alpha$-D-bromoxylopyranose (9)}

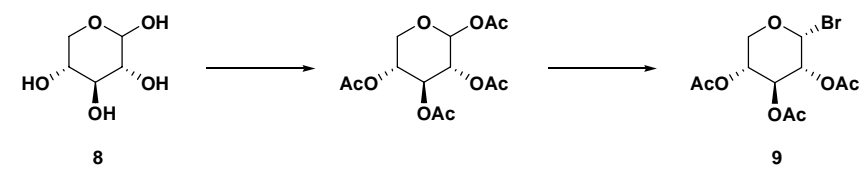

Acetylation: Acetic anhydride $(50 \mathrm{~mL})$ and pyridine $(50 \mathrm{~mL})$ were added to D-xylose $(8)(10 \mathrm{~g}, 66.6$ mmol) at $0{ }^{\circ} \mathrm{C}$. The reaction mixture was stirred at $0{ }^{\circ} \mathrm{C}$ for $24 \mathrm{~h}$. After $24 \mathrm{~h}$, the mixture was poured into water and diethyl ether was added. This reaction mixture was transferred to a separatory funnel and the organic layer was washed with sat. Cupric sulfate solution until pyridine was disappeared. The combined organic layers were dried over anhydrous $\mathrm{MgSO}_{4}$. Filtration was followed by evaporation in vacuo to afford crude product. The crude product was purified on silica gel (EtOAc:Hex $=1: 1$ ) to afford

2 (a) Son, J. B.; Kim, S. N.; Kim, N. Y.; Lee, D. H. Org. Lett. 2006, 8, 661-664. (b) Son, J. B.; Kim, S. N.; Kim, N. Y.; Lee, D. H. Org. Lett. 2006, 8, 3411.

3 (a) Satgé, C.; Jean Le Bras, J.; Hénin, F; Muzart, J. Tetrahedron 2005, 61, 8405-8409. (b) Yu, W.; Jin, Z. J. Am. Chem. Soc. 2002, 124, 6576-6583. (c) Rye, C. S.; Withers, S. G. J. Org. Chem. 2002, 67, 4505-4512. (d) Mitchell, S. A.; Pratt, M. R.; Hruby, V. J.; Polt, R. J. Org. Chem. 2001, 66, 2327-2342. (e) Yu, W.; Jin, Z. J. Am. Chem. Soc. 2001, 123, 3369-3370. (f) Schroeder, L. R.; Counts, K. M.; Haigh, F. C. Carbohydr. Res. 1974, 37, 368-372. 
tetraacetate $(21 \mathrm{~g}, 100 \%)$ as a yellow oil. The ${ }^{1} \mathrm{H}$ NMR data was consistent with those previously reported. $^{4}$

Bromination: A solution of commercial $\mathrm{HBr} /$ acetic acid $(30 \mathrm{wt} \%, 8.5 \mathrm{~mL}$ ) was added to tetraacetate $(2.5$ $\mathrm{g}, 7.86 \mathrm{mmol})$ at room temperature. The reaction was so rapid that the reading bad become constant within the first two minutes. The solution was poured into chloroform and the mixture was washed successively with ice-water, iced sodium bicarbonate solution, and ice-water again, and was then dried with $\mathrm{CaCl}_{2}$ and evaporated in vacuo. The syrup was crystallized from ether and hexane and acetobromoxylose 9 (2.43 g, 91\%) was obtained as a white solid: mp: $102-104^{\circ} \mathrm{C} ;{ }^{1} \mathrm{H}$ NMR $\left(\mathrm{CDCl}_{3}, 300\right.$ MHz) $\delta=6.58(\mathrm{~d}, J=3.9 \mathrm{~Hz}, 1 \mathrm{H}), 5.56(\mathrm{t}, J=9.9 \mathrm{~Hz}, 1 \mathrm{H}), 5.03(\mathrm{ddd}, J=10.8,9.6,6 \mathrm{~Hz}, 1 \mathrm{H}), 4.77(\mathrm{dd}$, $J=9.9,3.9 \mathrm{~Hz}, 1 \mathrm{H}), 4.05$ (dd, $J=11.4,6 \mathrm{~Hz}, 1 \mathrm{H}), 3.88(\mathrm{t}, J=11.4 \mathrm{~Hz}, 1 \mathrm{H}), 2.10(\mathrm{~s}, 3 \mathrm{H}), 2.05(\mathrm{~s}, 6 \mathrm{H})$ ppm

\section{Preparation of 3,4-di-O-acetyl-1,2-O-(1-ethoxyethylidene)-D-xylopyranose (10) ${ }^{5}$}

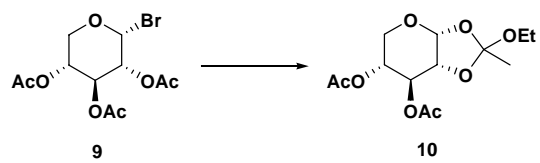

Orthoester formation: A mixture of acetobromoxylose 9 (29.9 g, $88.3 \mathrm{mmol})$, 2,4-lutidine (13.4 mL, $114.8 \mathrm{mmol})$, and tetrabutylammonium bromide $(11.4 \mathrm{~g}, 35.3 \mathrm{mmol})$ in anhydrous $\mathrm{CH}_{2} \mathrm{Cl}_{2}(176 \mathrm{~mL})$ was stirred at room temperature, and $\mathrm{EtOH}(5.67 \mathrm{~mL}, 97.13 \mathrm{mmol})$ was added. The reaction mixture was stirred at room temperature for $24 \mathrm{~h}$. TLC (EtOAc:Hex = 1:1) indicated that the reaction was complete. The reaction mixture was concentrated to give crude product. The residue was purified by silica gel chromatography (EtOAc:Hex $=1: 2)$ to provide orthoester $10(24.11 \mathrm{~g}, 90 \%)$ as a liquid: ${ }^{1} \mathrm{H}$ NMR (300 $\left.\mathrm{MHz}, \mathrm{CDCl}_{3}\right): \delta=5.55(\mathrm{~d}, J=4.2 \mathrm{~Hz}, 1 \mathrm{H}), 5.24(\mathrm{t}, J=3 \mathrm{~Hz}, 1 \mathrm{H}), 4.81(\mathrm{~m}, 1 \mathrm{H}), 4.18(\mathrm{t}, J=3.3 \mathrm{~Hz}, 1$ H), 3.90 (dd, $J=12,5.1 \mathrm{~Hz}, 1 \mathrm{H}), 3.68$ (dd, $J=12.3,6.9 \mathrm{~Hz}, 1 \mathrm{H}), 3.54$ (q, $J=6.9 \mathrm{~Hz}, 2 \mathrm{H}), 2.10$ (s, $3 \mathrm{H}$ ), 2.08 (s, $3 \mathrm{H}), 1.72$ (s, $3 \mathrm{H}), 1.18$ (t, $J=6.9 \mathrm{~Hz}, 3 \mathrm{H}) \mathrm{ppm} ;{ }^{13} \mathrm{C} \mathrm{NMR}\left(75 \mathrm{MHz}, \mathrm{CDCl}_{3}\right): \delta=170.0,169.2$, $122.3,96.6,74.3,68.8,67.5,59.9,58.6,22.7,20.9(2), 15.3 \mathrm{ppm}$

Preparation of 1,2-di-O-acetyl-3,4-di-O-methyl-D-xylopyranose (11)

\footnotetext{
${ }^{4}$ Utille, J. P.; Gagnaire, D. Carbohydrate Research, 1982, 106, 43-57.

5 Zhang, J.; Zhu, Y.; Kong, F. Carbohydr. Res. 2001, 336, 229-235.
} 


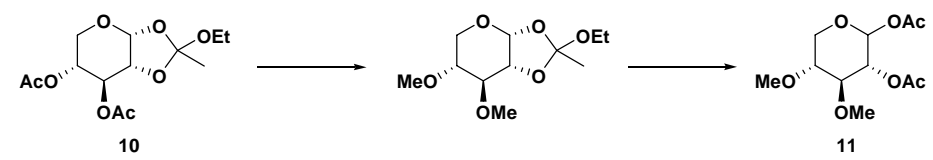

Methylation: A solution of acetate $10(7.6 \mathrm{~g}, 25.03 \mathrm{mmol})$ in $\mathrm{MeOH}(120 \mathrm{~mL})$ was treated with a catalytic amount of sodium methoxide at room temperature for $30 \mathrm{~min}$. The reaction mixture was concentrated. The residue was dissolved in DMF $(84 \mathrm{~mL})$ and treated with sodium hydride at $0{ }^{\circ} \mathrm{C}$. The reaction was stirred at room temperature for $1 \mathrm{~h}$ and then treated dropwise with methyl iodide $(4.1 \mathrm{~mL}$, $65.1 \mathrm{mmol}$ ) at $0{ }^{\circ} \mathrm{C}$. Stirring was continued at $\mathrm{rt}$ for an additional overnight, after which unreacted sodium hydride was destroyed by slow addition of $\mathrm{MeOH}$ at $0{ }^{\circ} \mathrm{C}$. The reaction mixture was diluted with ethyl acetate, and the organic phase was washed with water and brine, then dried $\left(\mathrm{Na}_{2} \mathrm{SO}_{4}\right)$, and concentrated under reduced pressure. Purification via flash chromatography (EtOAc:Hex = 1:2) gave methyl ether $(5.78 \mathrm{~g}, 93 \%)$ as a colorless oil: ${ }^{1} \mathrm{H}$ NMR $\left(300 \mathrm{MHz}, \mathrm{CDCl}_{3}\right): \delta=5.56(\mathrm{~d}, J=4.8 \mathrm{~Hz}, 1 \mathrm{H}), 4.27$ (ddd, $J$ $=3.6,3,0.6 \mathrm{~Hz}, 1 \mathrm{H}), 3.84(\mathrm{dd}, J=11.7,5.4 \mathrm{~Hz}, 1 \mathrm{H}), 3.60-3.52(\mathrm{~m}, 5 \mathrm{H}), 3.50(\mathrm{~s}, 3 \mathrm{H}), 3.44(\mathrm{~s}, 3 \mathrm{H})$, 3.41-3.34 (m, $1 \mathrm{H}), 1.69(\mathrm{~s}, 3 \mathrm{H}), 1.19(\mathrm{t}, J=6.9 \mathrm{~Hz}, 3 \mathrm{H}) \mathrm{ppm}$

Acetylation: Orthoester $(5.78 \mathrm{~g}, 23.27 \mathrm{mmol})$ was dissolved in $46 \mathrm{~mL}$ of acetic acid. The solution was maintained at $0{ }^{\circ} \mathrm{C}$ for $1 \mathrm{~h}$. The reaction mixture was concentrated, and the residue was treated with 20 $\mathrm{mL}$ of acetic anhydride and $20 \mathrm{~mL}$ of pyridine, and the resulting solution was maintained at room temperature for 1 day. The mixture was poured into water and diethyl ether was added. This reaction mixture was transferred to a separatory funnel and the organic layer was washed with sat. Cupric sulfate solution until pyridine was disappeared. The combined organic layer was dried over anhydrous $\mathrm{MgSO}_{4}$. Filtration was followed by evaporation in vacuo to afford crude product as a mixture of epimers $(\alpha: \beta=$ 1:2). The crude product was purified on silica gel (EtOAc:Hex = 1:1) to afford pure product 11 (6.0 g, 98\%) as a yellow oil: ${ }^{1} \mathrm{H}$ NMR $\left(300 \mathrm{MHz}, \mathrm{CDCl}_{3}\right)$ : For $\alpha$-isomer, $\delta 5.62(\mathrm{~d}, J=7.2 \mathrm{~Hz}, 1 \mathrm{H}), 4.86(\mathrm{dd}$, $J=3.6,9.6 \mathrm{~Hz}, 1 \mathrm{H}), 3.87(\mathrm{q}, J=5.6 \mathrm{~Hz}, 1 \mathrm{H}), 3.56(\mathrm{~s}, 3 \mathrm{H}), 3.50(\mathrm{~s}, 3 \mathrm{H}), 3.44-3.01(\mathrm{~m}, 4 \mathrm{H}), 2.14(\mathrm{~s}, 3 \mathrm{H})$, $2.09(\mathrm{~s}, 3 \mathrm{H})$; For $\beta$-isomer, $\delta 6.16(\mathrm{~d}, J=3.6 \mathrm{~Hz}, 1 \mathrm{H}), 4.95(\mathrm{t}, J=7.2 \mathrm{~Hz}, 1 \mathrm{H}), 4.13-4.03(\mathrm{~m}, 1 \mathrm{H})$, 3.53 (s, $3 \mathrm{H}), 3.48$ (s, $3 \mathrm{H}), 3.44-3.01$ (m, $4 \mathrm{H}), 2.08$ (s, $3 \mathrm{H}), 2.07$ (s, 3H) ppm

\section{Preparation of 1,2-di-O-benzyl-3,4-di-O-methyl-D-xylopyranose (12)}

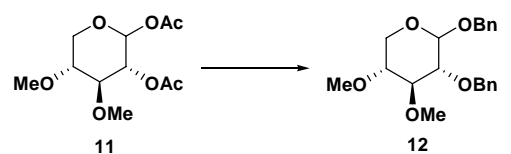

Benzylation: A solution of compound $11(6.0 \mathrm{~g}, 22.9 \mathrm{mmol})$ in $\mathrm{MeOH}(100 \mathrm{~mL})$ was treated with a 
catalytic amount of sodium methoxide at room temperature for $30 \mathrm{~min}$. The reaction mixture was concentrated. The residue was dissolved in DMF $(78 \mathrm{~mL})$ and treated with sodium hydride at $0{ }^{\circ} \mathrm{C}$. The reaction was stirred at room temperature for $1 \mathrm{~h}$ and then treated dropwise with benzyl bromide $(7.1 \mathrm{~mL}$, $59.5 \mathrm{mmol}$ ) at $0{ }^{\circ} \mathrm{C}$. Stirring was continued at $\mathrm{rt}$ for an additional overnight, after which unreacted sodium hydride was destroyed by slow addition of $\mathrm{MeOH}$ at $0{ }^{\circ} \mathrm{C}$. The reaction mixture was diluted with ethyl acetate, and the organic phase was washed with water and brine, then dried $\left(\mathrm{MgSO}_{4}\right)$, and concentrated under reduced pressure. Purification via flash chromatography (EtOAc:Hex =1:4) gave benzyl acetal 12 (5.99 $\mathrm{g}, 73 \%)$ as a yellow oil with epimeric ratio $(\alpha: \beta=1: 1)$; ${ }^{1} \mathrm{H} \mathrm{NMR}\left(300 \mathrm{MHz}, \mathrm{CDCl}_{3}\right)$ : For $\alpha$-isomer, $\delta$ 7.44-7.27 (m, $10 \mathrm{H}), 4.77(\mathrm{dd}, J=3.5 \mathrm{~Hz}, 1 \mathrm{H}), 4.75(\mathrm{~d}, J=12 \mathrm{~Hz}, 1 \mathrm{H}), 4.71(\mathrm{~d}, J=12 \mathrm{~Hz}, 1 \mathrm{H})$, $4.56(\mathrm{~d}, J=12 \mathrm{~Hz}, 1 \mathrm{H}), 4.54(\mathrm{~d}, J=12.5 \mathrm{~Hz}, 1 \mathrm{H}), 3.72(\mathrm{dd}, J=6,11 \mathrm{~Hz}, 1 \mathrm{H}), 3.70(\mathrm{~s}, 3 \mathrm{H}), 3.54$ (t, $J=$ $11 \mathrm{~Hz}, 1 \mathrm{H}), 3.52$ (s, $3 \mathrm{H}), 3.38$ (dd, $J=3.5,9 \mathrm{~Hz}, 1 \mathrm{H}), 3.27$ (ddd, $J=6,8.5,11 \mathrm{~Hz}, 1 \mathrm{H}), 3.24$ (t, $J=9$ $\mathrm{Hz}, 1 \mathrm{H}) \mathrm{ppm}$; For $\beta$-isomer, $\delta$ 7.44-7.27 (m, $10 \mathrm{H}), 4.94(\mathrm{~d}, J=11.5 \mathrm{~Hz}, 1 \mathrm{H}), 4.92(\mathrm{~d}, J=11 \mathrm{~Hz}, 1 \mathrm{H})$, $4.74(\mathrm{~d}, J=11 \mathrm{~Hz}, 1 \mathrm{H}), 4.67(\mathrm{~d}, J=12 \mathrm{~Hz}, 1 \mathrm{H}), 4.67(\mathrm{~d}, J=8 \mathrm{~Hz}, 1 \mathrm{H}), 4.07(\mathrm{dd}, J=5.5,11.5 \mathrm{~Hz}, 1 \mathrm{H})$, 3.65 (s, $3 \mathrm{H}), 3.62$ (t, $J=9 \mathrm{~Hz}, 1 \mathrm{H}), 3.51(\mathrm{~s}, 3 \mathrm{H}), 3.34(\mathrm{~m}, 1 \mathrm{H}), 3.18(\mathrm{dd}, J=10,11.5 \mathrm{~Hz}, 1 \mathrm{H}) \mathrm{ppm}$

Preparation of $\quad(2 R, 3 R, 4 S, 5 R)-3-(b e n z y l o x y)-4,5-d i m e t h o x y-t e t r a h y d r o-2 H-p y r a n-2-y l \quad 2,2,2-$ trichloroacetimidate (13)

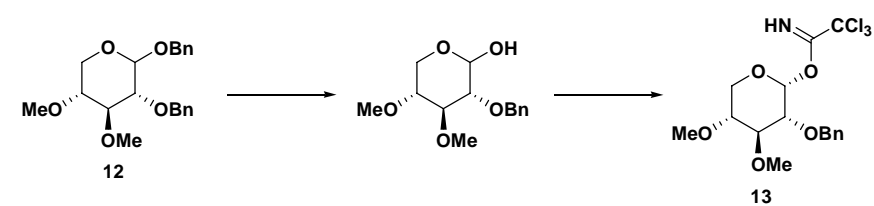

Hydrolysis: To a solution of benzyl acetal $12(151.1 \mathrm{mg}, 0.422 \mathrm{mmol})$ in 1,4-dioxane $(1.5 \mathrm{~mL})$ was added $2 \mathrm{~N} \mathrm{HCl}(1.5 \mathrm{~mL})$. The reaction mixture was refluxed for $24 \mathrm{~h}$. After allowing the mixture to cool to rt, the solvent removed in vacuo. The mixture was diluted with ethyl acetate and then neutralized with aqueous $\mathrm{NaHCO}_{3}$ to give a solution of $\mathrm{pH}$ 6-7. This aqueous solution was extracted with ether (x3) and the combined organic extracts washed with brine, dried $\mathrm{MgSO}_{4}$ and concentrated in vacuo. The residue is purified by flash chromatography $(\mathrm{Hex}:$ EtOAc $=1: 1)$ to give mixture hemiacetal $(58.4 \mathrm{mg}, 52 \%)$ with epimeric ratio $(\alpha: \beta=1: 1)$ as a solid: $\mathrm{mp}: 63-65^{\circ} \mathrm{C}{ }^{; 1} \mathrm{H}$ NMR (300 MHz, $\left.\mathrm{CDCl}_{3}\right): \delta=7.37-7.30(\mathrm{~m}, 5 \mathrm{H})$, 5.09 (t, $J=5 \mathrm{~Hz}, 1 \mathrm{H}), 4.78(\mathrm{~d}, J=10 \mathrm{~Hz}, 1 \mathrm{H}), 4.66(\mathrm{~d}, J=10 \mathrm{~Hz}, 1 \mathrm{H}), 3.71(\mathrm{~d}, J=12.5 \mathrm{~Hz}, 2 \mathrm{H}), 3.63$ (s, $3 \mathrm{H}), 3.48$ (s, $3 \mathrm{H}), 3.39$ (dd, $J=6,14.5 \mathrm{~Hz}, 1 \mathrm{H}), 3.22(\mathrm{t}, J=13 \mathrm{~Hz}, 1 \mathrm{H}), 2.88(\mathrm{~d}, J=5 \mathrm{~Hz}, 1 \mathrm{H})$ ppm; ${ }^{13} \mathrm{C}$ NMR $\left(125 \mathrm{MHz}, \mathrm{CDCl}_{3}\right): \delta=138.0,128.7,128.5,128.2,97.7,91.6,82.14,82.13,79.3,73.5$, $63.3,58.9 \mathrm{ppm}$

Imidate formation: To a solution of hemiacetal $(200 \mathrm{mg}, 0.75 \mathrm{mmol})$ in trichloroacetonitrile $(0.33 \mathrm{~mL}$, 
$3.28 \mathrm{mmol})$ and $\mathrm{CH}_{2} \mathrm{Cl}_{2}(5 \mathrm{~mL})$ was added $\mathrm{NaH}(18 \mathrm{mg}, 0.45 \mathrm{mmol})$ at $\mathrm{rt}$. After $3 \mathrm{~h}$ reaction time, the mixture was filtered through Celite, the solvents are evaporated, and the residue is purified by flash chromatography (Hex:EtOAc $=3: 1)$ to give imidate $13(274.9 \mathrm{mg}, 89 \%)$ with epimeric ratio $(\alpha: \beta=5: 1)$ as a pale yellow oil; ${ }^{1} \mathrm{H}$ NMR for $\alpha$-isomer $\left(300 \mathrm{MHz}, \mathrm{CDCl}_{3}\right)$ : $\delta=8.49(\mathrm{~s}, 1 \mathrm{H}), 7.25(\mathrm{~m}, 5 \mathrm{H}), 6.23(\mathrm{~d}$, $J=3.5 \mathrm{~Hz}, 1 \mathrm{H}), 4.63$ (d, $J=3.5 \mathrm{~Hz}, 2 \mathrm{H}), 3.80$ (dd, $J=6,11.5 \mathrm{~Hz}, 1 \mathrm{H}), 3.59$ (s, $3 \mathrm{H}), 3.54$ (t, $J=5.5 \mathrm{~Hz}$, $1 \mathrm{H}), 3.48$ (dd, $J=5,9 \mathrm{~Hz}, 1 \mathrm{H}), 3.43(\mathrm{~s}, 3 \mathrm{H}), 3.27(\mathrm{~m}, 1 \mathrm{H}), 3.25(\mathrm{dd}, J=6,8 \mathrm{~Hz}, 1 \mathrm{H}) \mathrm{ppm} ;{ }^{13} \mathrm{C} \mathrm{NMR}$ $\left(125 \mathrm{MHz}, \mathrm{CDCl}_{3}\right): \delta=161.6,138.2,128.5,127.9,127.6,94.5,82.6,79.2,76.9,73.1,62.1,61.4,59.3$ ppm

Preparation of methyl 2-((2S,3S,4S,6R)-4-((2S,3R,4S,5R)-3-(benzyloxy)-4,5-dimethoxy-tetrahydro2H-pyran-2-yloxy)-6-((S)-2-(4-methoxybenzyloxy)-2-((1R,2R)-2-methylcyclopropyl)ethyl)-3-methyltetrahydro-2H-pyran-2-yl)acetate (15)
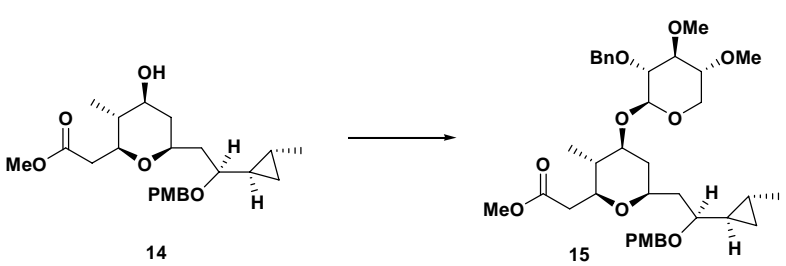

Glycosylation: A suspension of secondary alcohol 14 (94.6 $\mathrm{mg}, 0.232 \mathrm{mmol})$, trichloroacetimidate 13 (144 mg, $0.349 \mathrm{mmol}$ ), and molecular sieves $4 \AA$ ( $400 \mathrm{mg}$ ) in $\mathrm{CH}_{2} \mathrm{Cl}_{2}$ and $\mathrm{CH}_{3} \mathrm{CN}$ (4.5 mL each) was stirred for $20 \mathrm{~min}$ at ambient temperature. The resulting solution was cooled to $-50{ }^{\circ} \mathrm{C}$. TMSOTf $(8 \mu \mathrm{L})$ is added and the mixture was stirred $30 \mathrm{~min}$ at that temperature. The reaction was quenched with triethylamine. After the mixture was filtered through a pad of Celite, filtrate was concentrated in vacuo. The residue was diluted with $\mathrm{Et}_{2} \mathrm{O}$ and washed with sat. aq. $\mathrm{NaHCO}_{3}$ and brine. The combined organic layers were dried over $\mathrm{MgSO}_{4}$, filtered, evaporated to give crude product. The crude was purified by column chromatography (Hex:EtOAc $=1: 2)$ to give glycoside 15 in $47 \%$ yield $(71.7 \mathrm{mg}$ ) as a liquid: $[\alpha]_{D}^{25}=-18.5\left(\mathrm{c}=0.70, \mathrm{CHCl}_{3}\right)$; IR (film): $\widetilde{v}=3056,3031,2921,2847,1736,1617,1511,1454,1258$, 1082, 1017, $816 \mathrm{~cm}^{-1}$; ${ }^{1} \mathrm{H}$ NMR (300 MHz, $\left.\mathrm{CDCl}_{3}\right): \delta=7.37-7.27(\mathrm{~m}, 5 \mathrm{H}), 7.25(\mathrm{~d}, J=.87 \mathrm{~Hz}, 2 \mathrm{H})$, $6.87(\mathrm{~d}, J=8.7 \mathrm{~Hz}, 2 \mathrm{H}), 4.86(\mathrm{~d}, J=10.8 \mathrm{~Hz}, 1 \mathrm{H}), 4.72(\mathrm{~d}, J=10.8 \mathrm{~Hz}, 1 \mathrm{H}), 4.61(\mathrm{~d}, J=11.4 \mathrm{~Hz}, 1 \mathrm{H})$, $4.37(\mathrm{~d}, J=11.4 \mathrm{~Hz}, 1 \mathrm{H}), 4.36(\mathrm{~d}, J=7.5 \mathrm{~Hz}, 1 \mathrm{H}), 3.97$ (dd, $J=5.1,11.4 \mathrm{~Hz}, 1 \mathrm{H}), 3.80(\mathrm{~s}, 3 \mathrm{H}), 3.63$ (m, $1 \mathrm{H})), 3.61(\mathrm{~s}, 3 \mathrm{H}), 3.60(\mathrm{~s}, 3 \mathrm{H}), 3.47(\mathrm{~s}, 3 \mathrm{H}), 3.43(\mathrm{dt}, J=3,10.2 \mathrm{~Hz}, 1 \mathrm{H}), 3.34-3.18(\mathrm{~m}, 4 \mathrm{H})$, 3.09 (t, $J=10.5 \mathrm{~Hz}, 1 \mathrm{H}), 2.79$ ( dt, $J=6.9,7.5 \mathrm{~Hz}, 1 \mathrm{H}), 2.61$ (dd, $J=3,14.7 \mathrm{~Hz}, 1 \mathrm{H}), 2.38$ (dd, $J=9.6$, $14.7 \mathrm{~Hz}, 1 \mathrm{H}), 2.06$ (dd, $J=3,7.5 \mathrm{~Hz}, 1 \mathrm{H}), 1.98$ (ddd, $J=6,8.4,14.1 \mathrm{~Hz}, 1 \mathrm{H}), 1.62$ (m, $1 \mathrm{H}), 1.49-1.34$ (m, $2 \mathrm{H}), 1.08$ (d, $J=6 \mathrm{~Hz}, 3 \mathrm{H}), 0.96$ (d, $J=6.3 \mathrm{~Hz}, 3 \mathrm{H}), 0.63$ (m, $1 \mathrm{H}), 0.47$ (m, $1 \mathrm{H}), 0.29$ (dt, $J=4.5$, $8.4 \mathrm{~Hz}, 1 \mathrm{H}), 0.21(\mathrm{dt}, J=4.8,8.4 \mathrm{~Hz}, 1 \mathrm{H}) \mathrm{ppm} ;{ }^{13} \mathrm{C} \mathrm{NMR}\left(125 \mathrm{MHz}, \mathrm{CDCl}_{3}\right): \delta=172.2,159.1,138.5$, $131.5,129.3,128.5,128.2,127.8,113.9,105.6,85.9,82.9,82.2,79.8,79.6,78.0,75.4,72.6,70.2,63.4$, 
61.3, 58.9, 55.5, 51.8, 42.6, 42.0, 40.4, 39.3, 23.5, 18.6, 13.2, 12.6, 9.6 ppm; HRMS: m/z calcd for $\mathrm{C}_{37} \mathrm{H}_{52} \mathrm{NaO}_{10}[\mathrm{M}+\mathrm{Na}]^{+}$679.3458, found 679.3456

Preparation of allyl 2-((2S,3S,4S,6R)-4-((2S,3R,4S,5R)-3-(benzyloxy)-4,5-dimethoxy-tetrahydro-2Hpyran-2-yloxy)-6-((S)-2-hydroxy-2-((1R,2R)-2-methylcyclopropyl)ethyl)-3-methyl-tetrahydro-2Hpyran-2-yl)acetate (16)

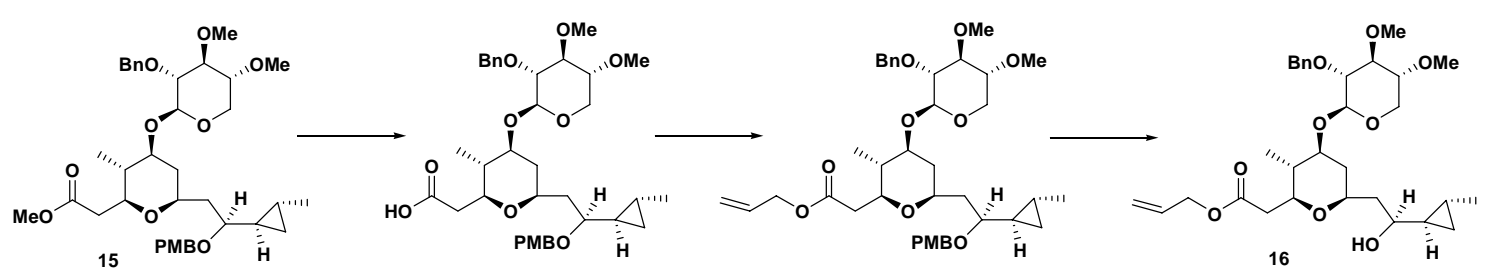

Hydrolysis: To a solution of methyl ester $15(71.7 \mathrm{mg}, 0.109 \mathrm{mmol})$ in $11 \mathrm{~mL}(10: 1: 1=$ THF: $\mathrm{H}_{2} \mathrm{O}: \mathrm{MeOH}$ ) is added $5.46 \mathrm{~mL}$ of a $1 \mathrm{M}$ aqueous solution of $\mathrm{LiOH}$. This suspension is stirred for 24 $\mathrm{h}$ and then diluted with water. The reaction solvent was removed in vacuo. The aqueous material is extracted with ethyl acetate (X3) and the combined organic extracts washed with brine, dried $\mathrm{MgSO}_{4}$ and concentrated in vacuo to give the acid $(64.3 \mathrm{mg})$. The crude product was used immediately in the next reaction without furification.

Esterification: To a solution of acid $(50.7 \mathrm{mg}, 78.9 \mu \mathrm{mol})$ in DMF $(0.8 \mathrm{~mL}), \mathrm{K}_{2} \mathrm{CO}_{3}(54.5 \mathrm{mg}, 0.394$ mmol) and allyl bromide $(33.4 \mu \mathrm{L}, 0.394 \mathrm{mmol})$ was added subsequently at $0{ }^{\circ} \mathrm{C}$. The reaction mixture was warmed to an $\mathrm{rt}$ and stirred for $12 \mathrm{~h}$ and quenched with aqueous $\mathrm{NH}_{4} \mathrm{Cl}$. This mixture was extracted with EtOAc and the combined organic layers were dried over $\mathrm{MgSO}_{4}$ and concentrated in vacuo. The residue was purified by flash chromatography an silica gel (EtOAc:Hex =1:2) to give allyl ester as a colorless oil (36.1 mg, 53\%, 2 steps): $[\alpha]_{D}^{25}=-18.5\left(c=0.415, \mathrm{CHCl}_{3}\right)$; IR (film): $\tilde{v}=3064,3027,2925$, 2864, 1740, 1613, 1511, 1450, 1368, 1245, 1164, 1086, 820, 751, $698 \mathrm{~cm}^{-1} ;{ }^{1} \mathrm{H}$ NMR (500 MHz, $\left.\mathrm{CDCl}_{3}\right)$ : $\delta=7.37-7.26(\mathrm{~m}, 5 \mathrm{H}), 7.25(\mathrm{~d}, J=9 \mathrm{~Hz}, 2 \mathrm{H}), 6.86(\mathrm{~d}, J=9 \mathrm{~Hz}, 2 \mathrm{H}), 5.88(\mathrm{~m}, 1 \mathrm{H}), 5.29(\mathrm{dd}, J=1.5$, $17.5 \mathrm{~Hz}, 1 \mathrm{H}), 5.20$ (dd, $J=1.5,10.5 \mathrm{~Hz}, 1 \mathrm{H}), 4.86$ (d, $J=10.5 \mathrm{~Hz}, 1 \mathrm{H}), 4.72$ (d, $J=10.5 \mathrm{~Hz}, 1 \mathrm{H}), 4.60$ $(\mathrm{d}, J=11 \mathrm{~Hz}, 1 \mathrm{H}), 4.53(\mathrm{~m}, 2 \mathrm{H}), 4.37(\mathrm{~d}, J=7.5 \mathrm{~Hz}, 1 \mathrm{H}), 4.36(\mathrm{~d}, J=11 \mathrm{~Hz}, 1 \mathrm{H}), 3.96(\mathrm{dd}, J=5,12$ Hz, 1 H), 3.79 (s, 3 H), 3.63 (m, 1 H), 3.61 (s, 3 H), 3.47 (s, 3 H), 3.45 (dt, J= 3.5, 9.5 Hz, 1 H), 3.32$3.24(\mathrm{~m}, 3 \mathrm{H}), 3.18$ (t, $J=9 \mathrm{~Hz}, 1 \mathrm{H}), 3.09$ (t, $J=10 \mathrm{~Hz}, 1 \mathrm{H}), 2.80$ (br q, $J=8 \mathrm{~Hz}, 1 \mathrm{H}), 2.64$ (dd, $J=3$, $14.5 \mathrm{~Hz}, 1 \mathrm{H}), 2.41$ (dd, $J=9,14.5 \mathrm{~Hz}, 1 \mathrm{H}), 2.06$ (dd, $J=4.5,6 \mathrm{~Hz}, 1 \mathrm{H}), 1.98$ (ddd, $J=6,8.5,14 \mathrm{~Hz}, 1$ H), $1.62(\mathrm{ddd}, J=5,7.5,12.5 \mathrm{~Hz}, 1 \mathrm{H}), 1.46(\mathrm{~m}, 1 \mathrm{H}), 1.07(\mathrm{~d}, J=6 \mathrm{~Hz}, 3 \mathrm{H}), 0.97$ (d, J=6.5 Hz, $3 \mathrm{H})$, $0.64(\mathrm{~m}, 1 \mathrm{H}), 0.48(\mathrm{~m}, 1 \mathrm{H}), 0.29(\mathrm{dt}, J=5,9.5 \mathrm{~Hz}, 1 \mathrm{H}), 0.21(\mathrm{dt}, J=5,9 \mathrm{~Hz}, 1 \mathrm{H}) \mathrm{ppm} ;{ }^{13} \mathrm{C}$ NMR $(125$ $\left.\mathrm{MHz}, \mathrm{CDCl}_{3}\right): \delta=171.4,159.1,138.5,132.3,131.5,129.2,128.5,128.3,127.9,118.4,113.9,105.6$, 
85.9, 83.0, 82.2, 79.8, 79.7, 78.0, 75.4, 72.6, 70.3, 65.4, 63.5, 61.3, 59.0, 55.4, 42.6, 42.0, 40.4, 39.5, 23.5, 18.6, 13.2, 12.6, 9.7 ppm; HRMS: $m / z$ calcd for $\mathrm{C}_{39} \mathrm{H}_{54} \mathrm{NaO}_{10}[M+\mathrm{Na}]^{+} 705.3615$, found 705.3619

Deprotection: To a solution of PMB ether $(33 \mathrm{mg}, 0.048 \mathrm{mmol})$ in $\mathrm{CH}_{2} \mathrm{Cl}_{2}(1.2 \mathrm{~mL})$ and water $(0.07 \mathrm{~mL})$ was added DDQ (12 mg, $0.053 \mathrm{mmol})$. The reaction mixture was stirred for $1 \mathrm{~h}$. After which time the mixture was filtered through a plug of filter aid, washed with $\mathrm{CH}_{2} \mathrm{Cl}_{2}$, dried over $\mathrm{MgSO}_{4}$ and concentrated. The residue was purified on silica gel using (Hex:EtOAc $=2: 1)$ as eluant, which gave the secondary alcohol $16(24.1 \mathrm{mg}, 89 \%)$ as a colorless oil: $[\alpha]_{D}^{25}=-18.9\left(c=0.275, \mathrm{CHCl}_{3}\right)$; IR (film): $\widetilde{v}=$ 3060, 3024, 2927, 1738, 1611, 1511, 1447, 1365, 1242, 1158, $1080 \mathrm{~cm}^{-1} ;{ }^{1} \mathrm{H}_{\mathrm{NMR}}\left(500 \mathrm{MHz}, \mathrm{CDCl}_{3}\right)$ : $\delta=7.36-7.27(\mathrm{~m}, 5 \mathrm{H}), 5.91(\mathrm{~m}, 1 \mathrm{H}), 5.31(\mathrm{~d}, J=17 \mathrm{~Hz}, 1 \mathrm{H}), 5.22(\mathrm{~d}, J=10 \mathrm{~Hz}, 1 \mathrm{H}), 4.84(\mathrm{~d}, J=10.5$ $\mathrm{Hz}, 1 \mathrm{H}), 4.72(\mathrm{~d}, J=10.5 \mathrm{~Hz}, 1 \mathrm{H}), 4.64-4.53$ (m, $2 \mathrm{H}), 4.36$ (d, $J=7.5 \mathrm{~Hz}, 1 \mathrm{H}), 3.96(\mathrm{dd}, J=5.5,12$ $\mathrm{Hz}, 1 \mathrm{H}), 3.62(\mathrm{~m}, 1 \mathrm{H}), 3.61(\mathrm{~s}, 3 \mathrm{H}), 3.50(\mathrm{dt}, J=2.5,10 \mathrm{~Hz}, 1 \mathrm{H}), 3.47(\mathrm{~s}, 3 \mathrm{H}), 3.31-3.24(\mathrm{~m}, 3 \mathrm{H})$, $3.17(\mathrm{t}, J=9 \mathrm{~Hz}, 1 \mathrm{H}), 3.09$ (m, $2 \mathrm{H}), 2.67(\mathrm{dd}, J=3,15.5 \mathrm{~Hz}, 1 \mathrm{H}), 2.43(\mathrm{dd}, J=10,15.5 \mathrm{~Hz}, 1 \mathrm{H}), 2.07$ $(\mathrm{dd}, J=5,12 \mathrm{~Hz}, 1 \mathrm{H}), 1.75(\mathrm{~m}, 1 \mathrm{H}), 1.66(\mathrm{dt}, J=2,15 \mathrm{~Hz}, 1 \mathrm{H}), 1.46(\mathrm{~m}, 2 \mathrm{H}), 1.04(\mathrm{~d}, J=5.5 \mathrm{~Hz}, 3$ H), $0.96(\mathrm{~d}, J=6.5 \mathrm{~Hz}, 3 \mathrm{H}), 0.75(\mathrm{~m}, 1 \mathrm{H}), 0.57(\mathrm{~m}, 1 \mathrm{H}), 0.29(\mathrm{dt}, J=4.5,9 \mathrm{~Hz}, 1 \mathrm{H}), 0.15(\mathrm{dt}, J=5,9$ $\mathrm{Hz}, 1 \mathrm{H}) \mathrm{ppm} ;{ }^{13} \mathrm{C} \mathrm{NMR}\left(125 \mathrm{MHz}, \mathrm{CDCl}_{3}\right): \delta=171.3,138.4,132.2,128.5,128.2,127.9,118.7,105.6$, $85.9,82.5,82.1,79.8,78.0,76.4,76.1,75.4,65.7,63.5,61.3,59.0,42.7,42.2,40.7,38.7,26.3,18.9,13.1$, 11.3, 10.4 ppm; HRMS: $m / z$ calcd for $\mathrm{C}_{31} \mathrm{H}_{46} \mathrm{NaO}_{9}[M+\mathrm{Na}]^{+} 585.3040$, found 585.3043

Preparation of 2-((2S,3S,4S,6R)-4-((2S,3R,4S,5R)-3-(benzyloxy)-4,5-dimethoxy-tetrahydro-2Hpyran-2-yloxy)-6-((S)-2-(4-methoxybenzyloxy)-2-((1R,2R)-2-methylcyclopropyl)ethyl)-3-methyltetrahydro-2H-pyran-2-yl)acetic acid (18)

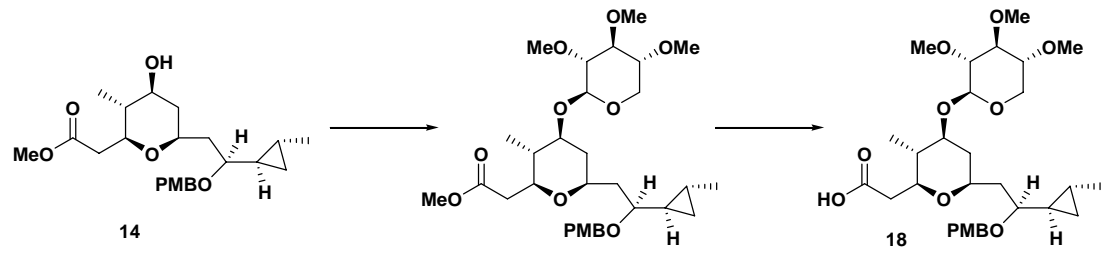

Glycosylation: A suspension of secondary alcohol 14 (94.6 mg, $0.232 \mathrm{mmol})$, trichloroacetimidate 17 (144 mg, $0.349 \mathrm{mmol}$ ), and molecular sieves $4 \AA$ (400 mg) in $\mathrm{CH}_{2} \mathrm{Cl}_{2}$ and $\mathrm{CH}_{3} \mathrm{CN}$ (4.5 mL each) was stirred for $20 \mathrm{~min}$ at ambient temperature. The resulting solution was cooled to $-50{ }^{\circ} \mathrm{C}$. TMSOTf $(8 \mu \mathrm{L})$ is added and the mixture was stirred $30 \mathrm{~min}$ at that temperature. The reaction was quenched with triethylamine. After the mixture was filtered through a pad of Celite, filtrate was concentrated in vacuo. The residue was diluted with $\mathrm{Et}_{2} \mathrm{O}$ and washed with sat. aq. $\mathrm{NaHCO}_{3}$ and brine. The combined organic layers were dried over $\mathrm{MgSO}_{4}$, filtered, evaporated to give crude product. The crude was purified by column chromatography (Hex:EtOAc $=1: 2)$ to give glycoside in $47 \%$ yield $(72 \mathrm{mg})$ as a colorless oil: 
$[\alpha]_{D}^{25}=-7.8\left(c=0.35, \mathrm{CHCl}_{3}\right)$; IR (film): $\widetilde{v}=3444,2990,2941,2864,1736,1613,1511,1433,1249$, 1168, 1078, 1037, $824 \mathrm{~cm}^{-1}$; ${ }^{1} \mathrm{H}$ NMR $\left(500 \mathrm{MHz}, \mathrm{CDCl}_{3}\right): \delta=7.24(\mathrm{~d}, J=8 \mathrm{~Hz}, 2 \mathrm{H}), 6.86(\mathrm{~d}, J=8 \mathrm{~Hz}$, $2 \mathrm{H}), 4.60(\mathrm{~d}, J=11.5 \mathrm{~Hz}, 1 \mathrm{H}), 4.37$ (d, $J=11.5 \mathrm{~Hz}, 1 \mathrm{H}), 4.26$ (d, $J=7.5 \mathrm{~Hz}, 1 \mathrm{H}), 3.95(\mathrm{dd}, J=5.5$, $11.5 \mathrm{~Hz}, 1 \mathrm{H}), 3.80$ (s, $3 \mathrm{H}), 3.61$ (s, $3 \mathrm{H}), 3.60$ (s, $3 \mathrm{H}), 3.59$ (s, $3 \mathrm{H}), 3.59$ (m, 1H), 3.46 (s, $3 \mathrm{H}), 3.44$ (m, $1 \mathrm{H}), 3.29-3.21$ (m, $2 \mathrm{H}), 3.11-3.05$ (m, $2 \mathrm{H}), 2.96$ (dd, $J=7.5,9 \mathrm{~Hz}, 1 \mathrm{H}), 2.78$ (br q, $J=7.5 \mathrm{~Hz}, 1 \mathrm{H}$ ), $2.63(\mathrm{dd}, J=3,15 \mathrm{~Hz}, 1 \mathrm{H}), 2.37$ (dd, $J=9.5,15 \mathrm{~Hz}, 1 \mathrm{H}), 2.05$ (dd, $J=4.5,10.5 \mathrm{~Hz}, 1 \mathrm{H}), 1.97$ (ddd, $J$ $=6,8.5,14.5 \mathrm{~Hz}, 1 \mathrm{H}), 1.61(\mathrm{~m}, 1 \mathrm{H}), 1.49-1.34(\mathrm{~m}, 2 \mathrm{H}), 1.07(\mathrm{~d}, J=6.5 \mathrm{~Hz}, 3 \mathrm{H}), 1.01(\mathrm{~d}, J=6 \mathrm{~Hz}, 3$ $\mathrm{H}), 0.62(\mathrm{~m}, 1 \mathrm{H}), 0.47(\mathrm{~m}, 1 \mathrm{H}), 0.28(\mathrm{dt}, J=4.5,8.5 \mathrm{~Hz}, 1 \mathrm{H}), 0.21(\mathrm{dt}, J=5,8.5 \mathrm{~Hz}, 1 \mathrm{H}) \mathrm{ppm} ;{ }^{13} \mathrm{C}$ $\operatorname{NMR}\left(125 \mathrm{MHz}, \mathrm{CDCl}_{3}\right): \delta=172.2,159.2,131.5,129.3,113.9,105.7,85.7,84.0,83.3,79.6,79.6,78.0$, 72.6, 70.2, 63.4, 61.0, 59.0, 55.5, 51.8, 42.6, 42.0, 40.4, 39.4, 23.5, 18.6, 12.9, 12.6, 9.6 ppm; HRMS: $\mathrm{m} / \mathrm{z}$ calcd for $\mathrm{C}_{31} \mathrm{H}_{48} \mathrm{NaO}_{10}[M+\mathrm{Na}]^{+}$603.3145, found 603.3140

Hydrolysis: To a solution of methyl ester $(30 \mathrm{mg}, 52.0 \mu \mathrm{mol})$ in $5.2 \mathrm{~mL}\left(10: 1: 1\right.$, THF : $\left.\mathrm{H}_{2} \mathrm{O}: \mathrm{MeOH}\right)$ is added $2.6 \mathrm{~mL}$ of a $1 \mathrm{M}$ aqueous solution of $\mathrm{LiOH}$. This suspension is stirred for $24 \mathrm{~h}$ and then diluted with water. The reaction solvent was removed in vacuo. The aqueous material is extracted with ethyl acetate (X3) and the combined organic extracts washed with brine, dried $\mathrm{MgSO}_{4}$ and concentrated in vacuo to give the acid $\mathbf{1 8}(31.1 \mathrm{mg})$. The crude product was used immediately in the next reaction without purification.

\section{Compound 19}

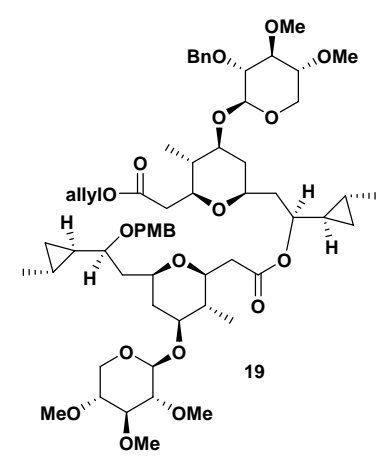

Esterification: To a solution of alcohol $16(78.9 \mathrm{mg}, 0.14 \mathrm{mmol})$, acid $18(103.3 \mathrm{mg}, 0.18 \mathrm{mmol})$ and DMAP (22.3 mg, $0.18 \mathrm{mmol})$ in $\mathrm{CH}_{2} \mathrm{Cl}_{2}$ was added DIC $\left(0.36 \mathrm{~mL}, 0.365 \mathrm{mmol}, 1 \mathrm{M}\right.$ solution in $\mathrm{CH}_{2} \mathrm{Cl}_{2}$ ) at $0{ }^{\circ} \mathrm{C}$. The mixture was allowed to warm to ambient temperature while stirring for 1 day. Evaporation of the solvent left a syrup which was purified by flash chromatography $(\mathrm{Hex}: \mathrm{EtOAc}=1: 1)$ to give ester $19(83.4 \mathrm{mg})$ in $54 \%$ yield as a colorless oil: $[\alpha]_{D}^{25}=-20.7\left(c=0.44, \mathrm{CHCl}_{3}\right)$; IR (film): $\widetilde{v}=3002,2929$, $2868,1728,1511,1249,1160,1086,751 \mathrm{~cm}^{-1} ;{ }^{1} \mathrm{H} \mathrm{NMR}\left(500 \mathrm{MHz}, \mathrm{CDCl}_{3}\right): \delta=7.38-7.27(\mathrm{~m}, 5 \mathrm{H})$, $7.26(\mathrm{~d}, J=8.5 \mathrm{~Hz}, 2 \mathrm{H}), 6.86(\mathrm{~d}, J=8.5 \mathrm{~Hz}, 2 \mathrm{H}), 5.94(\mathrm{~m}, 1 \mathrm{H}), 5.33(\mathrm{dd}, J=1.5,17.5 \mathrm{~Hz}, 1 \mathrm{H}), 5.24$ 
(dd, $J=1.5,10 \mathrm{~Hz}, 1 \mathrm{H}), 4.84(\mathrm{~d}, J=11 \mathrm{~Hz}, 1 \mathrm{H}), 4.71(\mathrm{~d}, J=11 \mathrm{~Hz}, 1 \mathrm{H}), 4.66(\mathrm{~d}, J=11 \mathrm{~Hz}, 1 \mathrm{H}), 4.61$ (d, $J=5.5 \mathrm{~Hz}, 2 \mathrm{H}), 4.40$ (m, $1 \mathrm{H}), 4.38$ (d, $J=9 \mathrm{~Hz}, 1 \mathrm{H}), 4.37$ (d, $J=7.5 \mathrm{~Hz}, 1 \mathrm{H}), 4.28$ (d, $J=7.5 \mathrm{~Hz}$, $1 \mathrm{H}), 3.96$ (dd, $J=5,10.5 \mathrm{~Hz}, 1 \mathrm{H}), 3.95(\mathrm{dd}, J=5,11.5 \mathrm{~Hz}, 1 \mathrm{H}), 3.78(\mathrm{~s}, 3 \mathrm{H}), 3.64(\mathrm{~m}, 1 \mathrm{H}), 3.63(\mathrm{~s}, 3$ H), 3.62 (s, 3 H), 3.60 (s, 3 H), 3.58 (m, 1 H), $3.48(\mathrm{~s}, 6$ H), 3.47 (m, 1 H), $3.45(\mathrm{~m}, 1 \mathrm{H}), 3.32-3.23$ (m, 6 H), 3.11 (t, $J=9 \mathrm{~Hz}, 1 \mathrm{H}), 3.08$ (t, $J=11.5 \mathrm{~Hz}, 1 \mathrm{H}), 2.98$ (t, $J=8.5 \mathrm{~Hz}, 1 \mathrm{H}), 2.82$ (br q, $J=7.5 \mathrm{~Hz}, 1 \mathrm{H}$ ), $2.63(\mathrm{dd}, J=2,12 \mathrm{~Hz}, 1 \mathrm{H}), 2.61(\mathrm{dd}, J=3.5,14.5 \mathrm{~Hz}, 1 \mathrm{H}), 2.43(\mathrm{dd}, J=9,14.5 \mathrm{~Hz}, 1 \mathrm{H}), 2.38(\mathrm{dd}, J=$ 8, $14.5 \mathrm{~Hz}, 1 \mathrm{H}), 2.08$ (br d, $J=12 \mathrm{~Hz}, 2 \mathrm{H}), 2.01(\mathrm{~m}, 1 \mathrm{H}), 1.89$ (m, $1 \mathrm{H}), 1.63(\mathrm{~m}, 2 \mathrm{H}), 1.41$ (m, $2 \mathrm{H})$, $1.09(\mathrm{~d}, J=5.5 \mathrm{~Hz}, 3 \mathrm{H}), 1.03(\mathrm{~d}, J=6.5 \mathrm{~Hz}, 3 \mathrm{H}), 0.98(\mathrm{~d}, J=5.5 \mathrm{~Hz}, 3 \mathrm{H}), 0.96(\mathrm{~d}, J=6.5 \mathrm{~Hz}, 3 \mathrm{H})$, 0.74 (m, $2 \mathrm{H}), 0.60-0.49$ (m, $3 \mathrm{H}), 0.30-0.21$ (m, $3 \mathrm{H}) \mathrm{ppm} ;{ }^{13} \mathrm{C} \mathrm{NMR}\left(125 \mathrm{MHz}, \mathrm{CDCl}_{3}\right): \delta=171.6$, 171.0, 159.1, 138.5, 132.4, 131.6, 129.2, 128.5, 128.2, 127.8, 118.5, 113.9, 105.7, 105.6, 85.8, 85.7, 84.0, $83.4,82.7,82.2,79.8,79.5,78.1,78.0,77.2,75.7,75.4,72.7,72.3,70.3,65.5,63.4,63.3,61.3,61.0,59.0$, 58.9, 55.4, 42.8, 42.4 41.9, 41.6, 40.7, 40.1, 39.9, 39.3, 23.7, 18.8, 18.5, 13.1, 12.9, 11.6, 11.0, 9.6 ppm; HRMS: $m / z$ calcd for $\mathrm{C}_{61} \mathrm{H}_{90} \mathrm{NaO}_{18}[M+\mathrm{Na}]^{+} 1133.6025$, found 1133.6028

\section{(-)-Clavosolide B (2)}

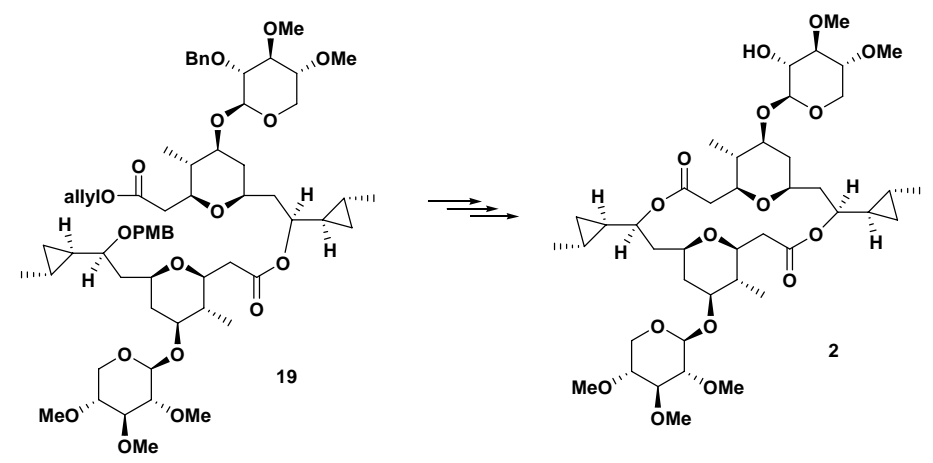

Deprotection of PMB ether: To a solution of PMB ether $19(83.4 \mathrm{mg}, 0.075 \mathrm{mmol})$ in $\mathrm{CH}_{2} \mathrm{Cl}_{2}(1.9 \mathrm{~mL})$ and water $(0.1 \mathrm{~mL})$ was added DDQ $(19 \mathrm{mg}, 0.082 \mathrm{mmol})$. The reaction mixture was stirred for $1 \mathrm{~h}$. After which time the mixture was filtered through a plug of filter aid, washed with $\mathrm{CH}_{2} \mathrm{Cl}_{2}$, dried over $\mathrm{MgSO}_{4}$ and concentrated. The residue was purified on silica gel using $(\mathrm{Hex}: \mathrm{EtOAc}=1: 1)$ as eluant, which gave the secondary alcohol $(51.7 \mathrm{mg}, 70 \%)$ as a colorless oil: $[\alpha]_{D}^{25}=-13.3\left(c=0.5, \mathrm{CHCl}_{3}\right)$; IR (film): $\widetilde{v}=$ $3513,3051,2929,1732,1454,1368,1262,1160,1082,739 \mathrm{~cm}^{-1} ;{ }^{1} \mathrm{H}$ NMR $\left(500 \mathrm{MHz}, \mathrm{CDCl}_{3}\right): \delta=7.39$ 7.27 (m, 5 H), 5.93 (m, 1 H), 5.33 (dd, J = 1.5, $17.5 \mathrm{~Hz}, 1 \mathrm{H}), 5.24$ (dd, J = 1.5, 10.5 Hz, $1 \mathrm{H}), 4.87$ (d, J = $11 \mathrm{~Hz}, 1 \mathrm{H}), 4.72(\mathrm{~d}, \mathrm{~J}=11 \mathrm{~Hz}, 1 \mathrm{H}), 4.60(\mathrm{~m}, 2 \mathrm{H}), 4.39(\mathrm{~d}, \mathrm{~J}=8 \mathrm{~Hz}, 1 \mathrm{H}), 4.36(\mathrm{~m}, 1 \mathrm{H}), 4.28(\mathrm{~d}, \mathrm{~J}=8$ Hz, 1 H), 3.99 (dd, J = 5.5, 12 Hz, 1 H), 3.96 (dd, J = 5.5, 11.5 Hz, 1 H), $3.63(\mathrm{~s}, 3 \mathrm{H}), 3.62$ (s, $3 \mathrm{H}), 3.60$ (s, 3 H), 3.58 (m, 1 H), 3.48 (s, 3 H), 3.47 (s, 3 H), 3.46 (m, 2 H), 3.14-3.23 (m, 4 H), 3.19 (t, J = 9 Hz, 1 H), 3.15-3.07 (m, 5 H), 2.98 (dd, J = 8, 9 Hz, 1 H), 2.63 (dd, J = 2.5, 15 Hz, 2 H), 2.45 (dd, J = 9, 15 Hz, 1 
H), 2.39 (dd, J = 8.5, $15 \mathrm{~Hz}, 1 \mathrm{H}), 2.09(\mathrm{br} \mathrm{d}, \mathrm{J}=7 \mathrm{~Hz}, 2 \mathrm{H}), 1.89(\mathrm{~m}, 1 \mathrm{H}), 1.74(\mathrm{~m}, 1 \mathrm{H}), 1.67$ (dd, J = 3.5, $14.5 \mathrm{~Hz}, 2 \mathrm{H}), 1.46$ (m, 4 H), $1.05(\mathrm{~d}, \mathrm{~J}=5.5 \mathrm{~Hz}, 3 \mathrm{H}), 1.03$ (d, J = 6 Hz, $3 \mathrm{H}), 0.98$ (d, J = $6 \mathrm{~Hz}, 3 \mathrm{H})$, 0.97 (d, J = 7 Hz, 3 H), 0.76 (m, 2 H), $0.63(\mathrm{~m}, 1 \mathrm{H}), 0.57$ (m, $1 \mathrm{H}), 0.51$ (dt, J = 5, 9.5 Hz, 1 H), 0.31 (dt, $\mathrm{J}=5,9 \mathrm{~Hz}, 1 \mathrm{H}), 0.26(\mathrm{dt}, \mathrm{J}=5,9.5 \mathrm{hz}, 1 \mathrm{H}), 0.16(\mathrm{dt}, \mathrm{J}=5,9 \mathrm{~Hz}, 1 \mathrm{H}) \mathrm{ppm} ;{ }^{13} \mathrm{C}$ NMR $(125 \mathrm{MHz}$, $\left.\mathrm{CDCl}_{3}\right): \quad \delta=171.5,170.8,138.5,132.4,128.5,128.2,127.8,118.4,105.8,105.6,85.9,85.7,83.9,82.9$, $82.7,82.2,79.8,79.5,78.3,77.9,77.2,76.3,76.1,75.5,75.4,72.4,66.0,65.5,63.4,61.3,61.0,60.9,59.0$, 42.9, 42.4, 42.3, 41.2, 40.7, 40.6, 39.4, 39.2, 26.4, 23.5, 18.9, 18.8, 15.4, 13.2, 12.8, 11.6, 11.2, 10.4 ppm; HRMS: $m / z$ calcd for $\mathrm{C}_{53} \mathrm{H}_{82} \mathrm{NaO}_{17}[M+\mathrm{Na}]^{+} 1013.5450$, found 1013.5431

Deprotection of allyl ester: To a solution of allyl ester $(13.5 \mathrm{mg}, 13.6 \mu \mathrm{mol})$ in THF $(1.5 \mathrm{~mL})$ was added $\mathrm{Pd}\left(\mathrm{PPh}_{3}\right)_{4}(2 \mathrm{mg}, 1.36 \mu \mathrm{mol})$ at $\mathrm{rt}$ under $\mathrm{N}_{2}$. After stirring for $15 \mathrm{~min}$, morpholine $(6 \mu \mathrm{L}, 68 \mu \mathrm{mol})$ was added. After $1 \mathrm{~h}$, the reaction mixture was quenched with $\mathrm{H}_{2} \mathrm{O}$ and extracted with ethyl acetate. The combined organic layers were washed with $\mathrm{H}_{2} \mathrm{O}$, dried over $\mathrm{MgSO}_{4}$ and concentrated in vacuo to give hydroxyl acid (13 mg). The crude product was used immediately in the next reaction without purification.

Macrolactonization: To a solution of the hydroxy acid $(13 \mathrm{mg}, 13.6 \mu \mathrm{mol})$ in dry THF $(0.5 \mathrm{~mL})$ were added TEA $(10 \mu \mathrm{L}, 68 \mu \mathrm{mol})$ and 2,4,6-trichlorobenzoyl chloride $(10 \mu \mathrm{L}, 57.2 \mu \mathrm{mol})$. After the reaction mixture was stirred at room temperature for $2 \mathrm{~h}$, TEA $\mathrm{HCl}$ salt was then filtered off, and the filterate was diluted with dry toluene ( $3 \mathrm{~mL}$ ) under $\mathrm{N}_{2}$. This solution was then added slowly to a solution of DMAP (35 $\mathrm{mg}$ ) in toluene $(12 \mathrm{~mL})$ under reflux. The reaction mixture was further stirred under reflux for $17 \mathrm{~h}$ and then diluted with water at room temperature. The mixture was extracted with ether (x3). The combined organic extracts were washed with brine, dried over $\mathrm{Na}_{2} \mathrm{SO}_{4}$, filtered, and concentrated in vacuo. Purification of the residue by flash chromatography (Hex:EtOAc $=3: 2)$ to give the macrolide $(6.6 \mathrm{mg}$, $52 \%$ in 2 steps) as a white solid: $[\alpha]_{D}^{25}=-35.6\left(c=0.57, \mathrm{CHCl}_{3}\right)$; IR (film): $\widetilde{v}=3051,2958,2921,1736$, 1266, 1160, 1086, 1021, $739 \mathrm{~cm}^{-1} ;{ }^{1} \mathrm{H}$ NMR $\left(500 \mathrm{MHz}, \mathrm{CDCl}_{3}\right): \delta=7.34-7.26(\mathrm{~m}, 5 \mathrm{H}), 4.86(\mathrm{~d}, J=11$ $\mathrm{Hz}, 1 \mathrm{H}), 4.61(\mathrm{~d}, J=11 \mathrm{~Hz}, 1 \mathrm{H}), 4.40(\mathrm{t}, J=8.5 \mathrm{~Hz}, 2 \mathrm{H}), 4.36(\mathrm{~d}, J=7.5 \mathrm{~Hz}, 1 \mathrm{H}), 4.26(\mathrm{~d}, J=7.5 \mathrm{~Hz}$, $1 \mathrm{H}), 3.96$ (m, 2 H), 3.61 (s, $3 \mathrm{H}), 3.60$ (s, $3 \mathrm{H}), 3.58$ (s, $3 \mathrm{H}), 3.47$ (s, $3 \mathrm{H}), 3.46$ (s, $3 \mathrm{H}), 3.51-3.42$ (m, 5 H), 3.27-3.23 (m, $5 \mathrm{H}), 3.17$ (t, $J=9 \mathrm{~Hz}, 1 \mathrm{H}), 3.12-3.06(\mathrm{~m}, 2 \mathrm{H}), 2.96(\mathrm{t}, J=8 \mathrm{~Hz}, 1 \mathrm{H}), 2.53$ (dt, $J=$ 3.5, $17.5 \mathrm{~Hz}, 2 \mathrm{H}$ ), 2.41 (dd, $J=6.5,17.5 \mathrm{~Hz}, 2 \mathrm{H}$ ), 2.07 (m, $2 \mathrm{H}$ ), 1.89 (m, $2 \mathrm{H}$ ), 1.68 (br d, $J=15 \mathrm{~Hz}, 2$ H), 1.38(m, 4 H), 0.97 (d, $J=6.5 \mathrm{~Hz}, 9 \mathrm{H}), 0.92$ (d, $J=6.5 \mathrm{~Hz}, 3 \mathrm{H}), 0.82(\mathrm{~m}, 2 \mathrm{H}), 0.71(\mathrm{~m}, 2 \mathrm{H}), 0.34$ (dt, $J=4.5,8.5 \mathrm{~Hz}, 2 \mathrm{H}), 0.21(\mathrm{dt}, J=4.5,8.5 \mathrm{~Hz}, 2 \mathrm{H}) \mathrm{ppm} ;{ }^{13} \mathrm{C} \mathrm{NMR}\left(125 \mathrm{MHz}, \mathrm{CDCl}_{3}\right): \delta=171.2$, $138.5,128.5,128.2,127.8,105.7,105.5,85.9,85.7,83.9,83.3,83.0,82.1,79.8,79.5,77.2,77.1,75.4$, 74.9, 63.5, 63.4, 61.3, 60.9, 60.6, 59.0, 42.7, 42.6, 41.4, 40.9, 39.3, 24.9, 18.7, 13.1, 12.8, 12.1, 11.0 ppm; HRMS: $m / z$ calcd for $\mathrm{C}_{50} \mathrm{H}_{76} \mathrm{NaO}_{16}[M+\mathrm{Na}]^{+} 955.5031$, found 955.5026

Debenzylation: A mixture of benzyl ether (12 mg, $12.9 \mu \mathrm{mol})$ and 10\% $\mathrm{Pd} / \mathrm{C}(7 \mathrm{mg})$, and absolute 
$\mathrm{MeOH}(1.2 \mathrm{~mL})$ was stirred under hydrogen atmosphere at ordinary pressure for $6 \mathrm{~h}$ at room temperature. The reaction mixture was filtered on a pad of Celite, and the filtrate was evaporated in vacuo to give crude alcohol. The crude product was purified by column chromatography (EtOAc:Hex $=1: 1$ ) to afford clavosolide B (2) $(8.5 \mathrm{mg}, 78 \%)$ as a white solid; $\mathrm{mp}: 205-207^{\circ} \mathrm{C} ;[\alpha]_{D}^{25}=-47.2\left(\mathrm{c}=0.4, \mathrm{CHCl}_{3}\right)\left(\mathrm{Lit}^{2}\right.$ $\left.[\alpha]_{D}^{25}=-41.0\left(\mathrm{c}=0.5, \mathrm{CHCl}_{3}\right)\right)^{6}$; IR (film): $\widetilde{v}=3465,2951,2858,1731,1434,1375,1254 \mathrm{~cm}^{-1} ;{ }^{1} \mathrm{H} \mathrm{NMR}$ $\left(500 \mathrm{MHz}, \mathrm{CDCl}_{3}\right): \delta=4.43($ br t $, J=8.5 \mathrm{~Hz}, 2 \mathrm{H}), 4.37(\mathrm{~d}, J=7 \mathrm{~Hz}, 1 \mathrm{H}), 4.27(\mathrm{~d}, J=7 \mathrm{~Hz}, 1 \mathrm{H}), 4.03$ (dd, $J=4.5,11.5 \mathrm{~Hz}, 1 \mathrm{H}), 3.97$ (dd, $J=4.5,11.5 \mathrm{~Hz}, 1 \mathrm{H}), 3.62$ (s, $3 \mathrm{H}), 3.61(\mathrm{~s}, 3 \mathrm{H}), 3.59$ (s, $3 \mathrm{H}), 3.48$ (s, $6 \mathrm{H}), 3.48-3.43(\mathrm{~m}, 5 \mathrm{H}), 3.30(\mathrm{~m}, 1 \mathrm{H}), 3.25(\mathrm{dt}, J=5,8 \mathrm{~Hz}, 2 \mathrm{H}), 3.25$ (dd, $J=8,11 \mathrm{~Hz}, 1 \mathrm{H}), 3.23$ (m, $1 \mathrm{H}), 3.21(\mathrm{t}, J=8 \mathrm{~Hz}, 1 \mathrm{H}), 3.10(\mathrm{t}, J=8.5 \mathrm{~Hz}, 1 \mathrm{H}), 3.09$ (dd, $J=9,11 \mathrm{~Hz}, 1 \mathrm{H}), 2.97$ (t, $J=8.5 \mathrm{~Hz}$, $1 \mathrm{H}), 2.55(\mathrm{dt}, J=3.5,17.5 \mathrm{~Hz}, 2 \mathrm{H}), 2.42(\mathrm{dd}, J=6.5,17.5 \mathrm{~Hz}, 2 \mathrm{H}), 2.05(\mathrm{dd}, J=4.5,12.5 \mathrm{~Hz}, 2 \mathrm{H})$, 1.90 (dt, $J=6.5,15 \mathrm{~Hz}, 1 \mathrm{H}), 1.89$ (dt, $J=6.5,15 \mathrm{~Hz}, 1 \mathrm{H}), 1.68$ (br d, $J=15 \mathrm{~Hz}, 2 \mathrm{H}), 1.40$ (m, $2 \mathrm{H})$, 1.38 (m, 2 H), 0.98 (d, $J=6.5 \mathrm{~Hz}, 9 \mathrm{H}), 0.95$ (d, $J=6.5 \mathrm{~Hz}, 3 \mathrm{H}), 0.83$ (m, $2 \mathrm{H}), 0.72$ (tt, $J=4.5,9 \mathrm{~Hz}, 2$ $\mathrm{H}), 0.35(\mathrm{dt}, J=4.5,8.5 \mathrm{~Hz}, 2 \mathrm{H}), 0.23(\mathrm{dt}, J=4.5,8.5 \mathrm{~Hz}, 2 \mathrm{H}) \mathrm{ppm} ;{ }^{13} \mathrm{C} \mathrm{NMR}\left(125 \mathrm{MHz}, \mathrm{CDCl}_{3}\right): \delta=$ 171.17, 171.14, 105.7, 104.8, 85.7, 84.0, 83.5, 83.4, 83.1, 79.6, 79.1, 77.14, 77.11, 75.04, 75.01, 73.0, 63.4, 62.6, 61.0, 60.4, 59.0, 58.6, 42.7, 42.5, 41.4, 40.9, 40.7, 39.4, 24.9, 18.7, 13.1, 12.8, 12.1, $11.1 \mathrm{ppm}$; HRMS: $\mathrm{m} / \mathrm{z}$ calcd for $\mathrm{C}_{44} \mathrm{H}_{72} \mathrm{NaO}_{16}[\mathrm{M}+\mathrm{Na}]^{+} 865.4562$, found 865.4563

(6) Rao, M. R.; Faulkner, D. J. J. Nat. Prod. 2002, 65, 386-388. 


\begin{tabular}{|c|c|c|}
\hline Assignment & $\begin{array}{l}\text { Isolated Clavosolide B } \\
\qquad\left(100 \mathrm{MHz}, \mathrm{CDCl}_{3}\right)\end{array}$ & $\begin{array}{c}\text { Synthetic Clavosolide B (2) } \\
\left(125 \mathrm{MHz}, \mathrm{CDCl}_{3}\right)\end{array}$ \\
\hline $1,1^{\prime}$ & 170.5 & $171.17,171.14$ \\
\hline 2,2 ' & 39.3 & 39.4 \\
\hline $3,3^{\prime}$ & 76.9 & 77.11 \\
\hline 4 & 42.7 & 42.7 \\
\hline $4^{\prime}$ & 42.5 & 42.5 \\
\hline 5 & 83.1 & 83.4 \\
\hline 5 & 82.9 & 83.1 \\
\hline 6 & 40.8 & 40.8 \\
\hline $6^{\prime}$ & 40.7 & 40.7 \\
\hline $7,7^{\prime}$ & 74.9 & $75.04,75.01$ \\
\hline $8,8^{\prime}$ & 41.4 & 41.4 \\
\hline $9,9^{\prime}$ & 77.2 & 77.14 \\
\hline $10,10^{\prime}$ & 25.0 & 24.9 \\
\hline $11,11^{\prime}$ & 12.2 & 12.1 \\
\hline 12,12 & 18.8 & 18.7 \\
\hline $13,13^{\prime}$ & 11.2 & 11.1 \\
\hline 14 & 12.9 & 12.8 \\
\hline $14^{\prime}$ & 13.2 & 13.1 \\
\hline 15 & 105.3 & 105.7 \\
\hline $15^{\prime}$ & 104.5 & 104.8 \\
\hline
\end{tabular}

SI-1-16 


\begin{tabular}{|l|l|l|}
\hline 16 & 83.8 & 84.0 \\
16, & 72.9 & 73.0 \\
17 & 85.6 & 85.7 \\
17, & 83.3 & 83.5 \\
18 & 79.4 & 79.5 \\
18, & 79.4 & 79.1 \\
19 & 63.2 & 63.4 \\
19, & 62.5 & 62.6 \\
20 & 60.8 & 61.0 \\
21 & 60.2 & 60.4 \\
21, & 60.8 & 61.0 \\
22 & 58.5 & 58.6 \\
22, & 58.8 & 59.0 \\
\hline
\end{tabular}

Comparison of ${ }^{1} \mathrm{H}$ NMR Spectra for Isolated and Synthetic Clavosolide B (2)

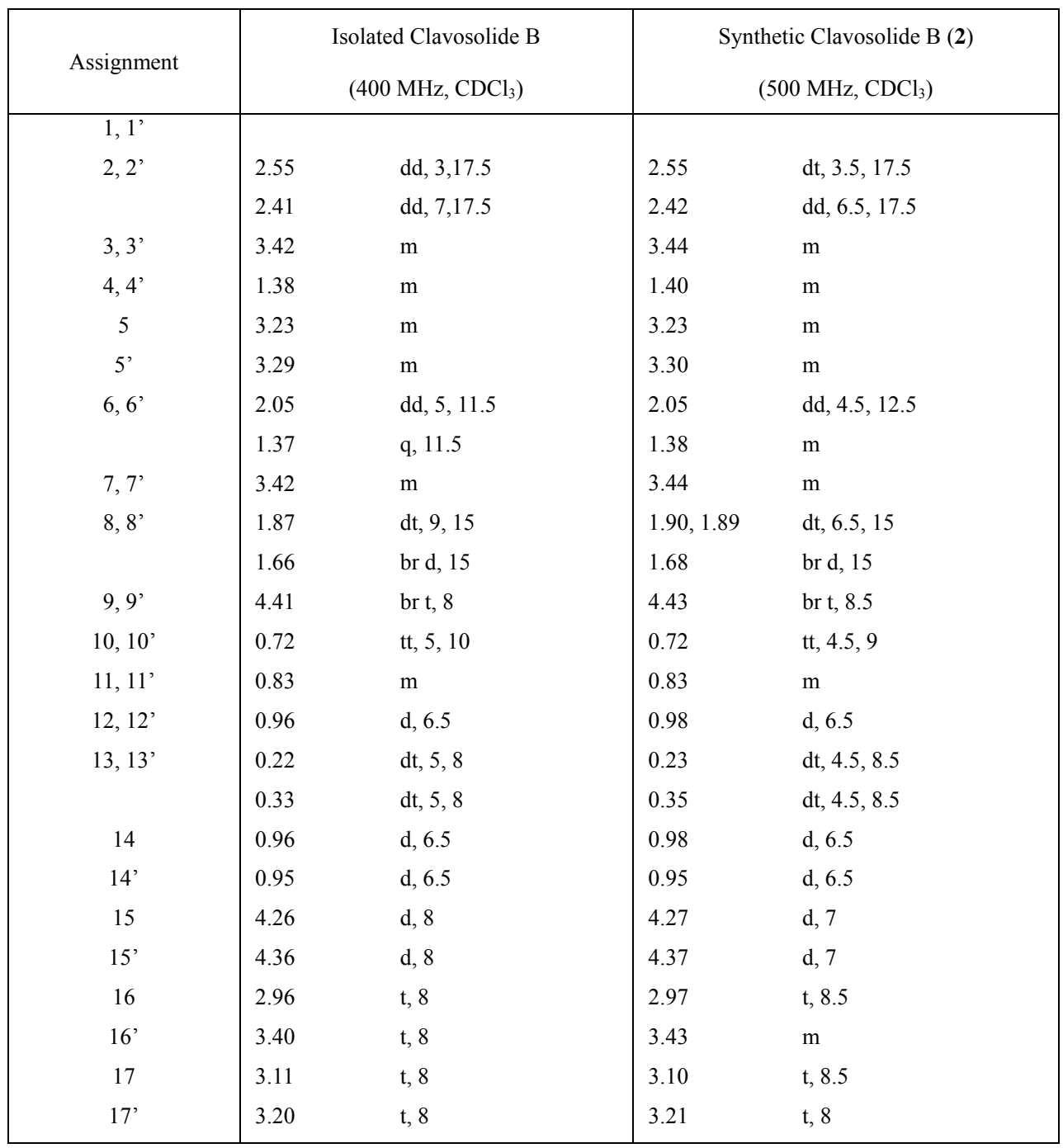




\begin{tabular}{|c|ll|ll|}
\hline $18,18^{\prime}$ & 3.25 & $\mathrm{dt}, 5,8$ & 3.25 & $\mathrm{dt}, 5,8$ \\
19 & 3.96 & $\mathrm{dd}, 5,11$ & 3.97 & $\mathrm{dd}, 4.5,11.5$ \\
& 3.10 & $\mathrm{dd}, 8,11$ & 3.09 & $\mathrm{dd}, 9,11$ \\
19 & 4.04 & $\mathrm{dd}, 5,11$ & 4.04 & $\mathrm{dd}, 4.5,11.5$ \\
& 3.25 & $\mathrm{dd}, 8,11$ & 3.25 & $\mathrm{dd}, 8,11$ \\
20 & 3.58 & $\mathrm{~s}$ & 3.59 & $\mathrm{~s}$ \\
21 & 3.62 & $\mathrm{~s}$ & 3.62 & $\mathrm{~s}$ \\
21 & 3.61 & $\mathrm{~s}$ & 3.61 & $\mathrm{~s}$ \\
22 & 3.47 & $\mathrm{~s}$ & 3.48 & $\mathrm{~s}$ \\
$22^{\prime}$ & 3.47 & $\mathrm{~s}$ & 3.48 & $\mathrm{~s}$ \\
\hline
\end{tabular}

SI-1-18 


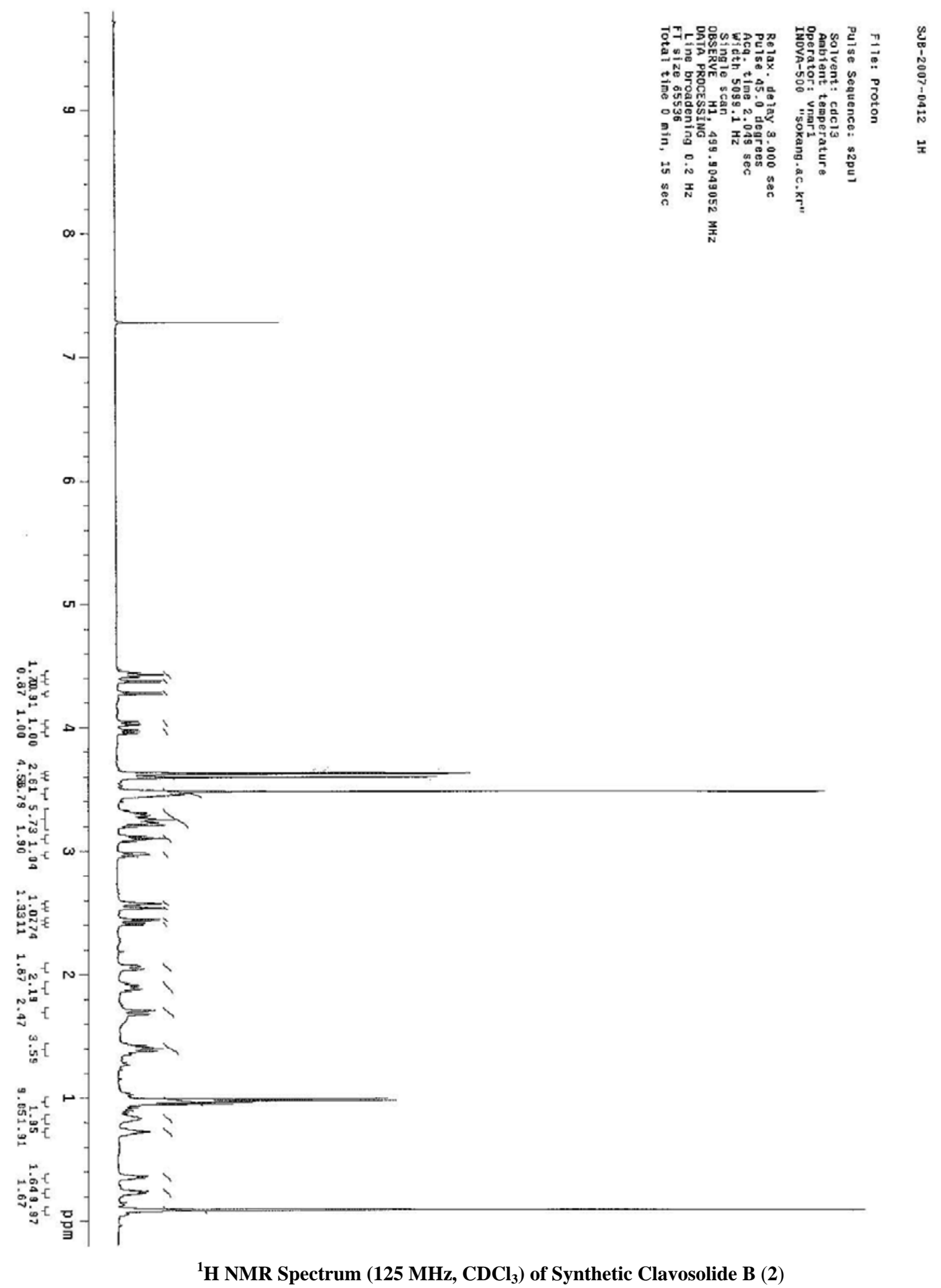

SI-1-19 


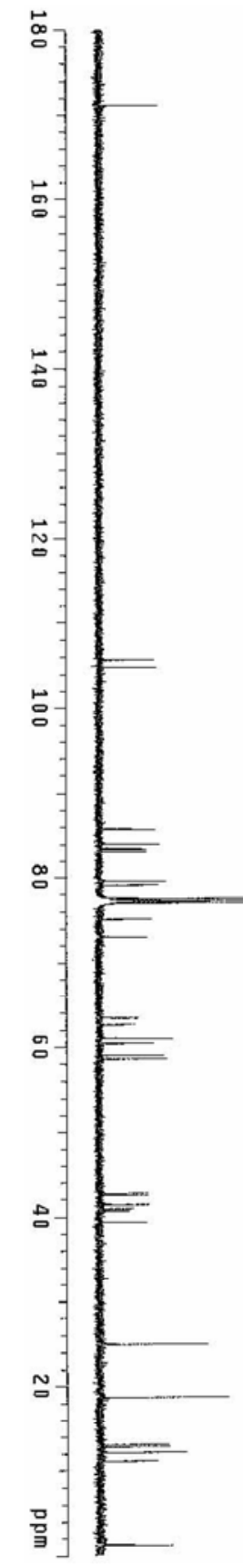

${ }^{13} \mathrm{C}$ NMR Spectrum (125 MHz, $\mathrm{CDCl}_{3}$ ) of Synthetic Clavosolide B (2) 


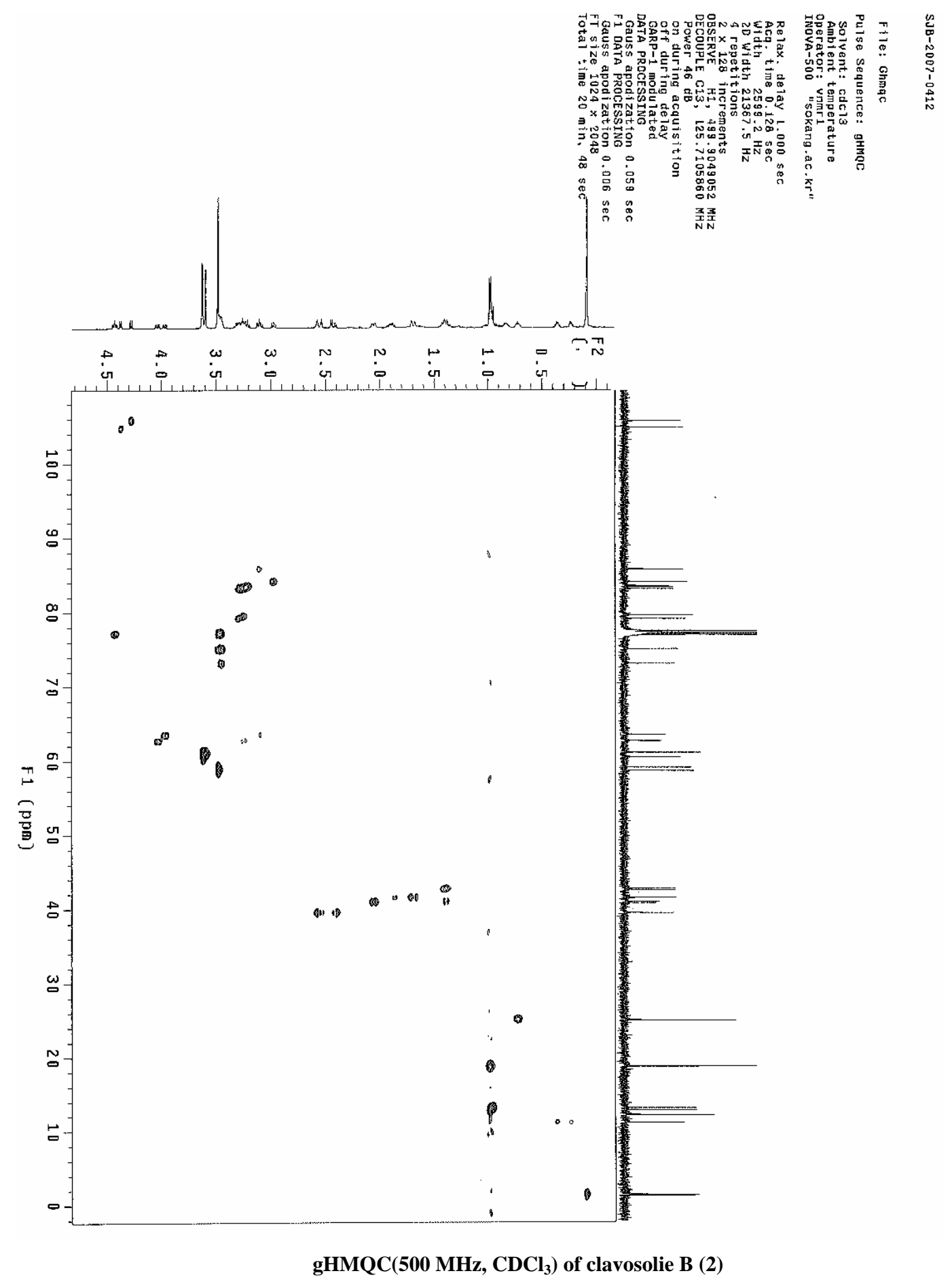

SI-1-21 